\title{
AUTOGENIC EROSIONAL SURFACES IN FLUVIO-DELTAIC STRATIGRAPHY FROM FLOODS, AVULSIONS, AND BACKWATER HYDRODYNAMICS
}

\author{
VAMSI GANTI, ${ }^{1,2}$ MICHAEL P. LAMB,${ }^{3}$ AND AUSTIN J. CHADWICK ${ }^{3}$ \\ ${ }^{1}$ Department of Geography, University of California Santa Barbara, Santa Barbara, California, U.S.A. \\ ${ }^{2}$ Department of Earth Science, University of California Santa Barbara, Santa Barbara, California, U.S.A. \\ ${ }^{3}$ Division of Geological and Planetary Sciences, California Institute of Technology, Pasadena, California, U.S.A. \\ e-mail:vganti@ucsb.edu
}

\begin{abstract}
Erosional surfaces set the architecture of fluvio-deltaic stratigraphy, and they have classically been interpreted in terms of changes in boundary conditions such as climate, tectonics, and base level (allogenic forces). Intrinsic dynamics of sedimentary systems (autogenic dynamics) can also create a rich stratigraphic architecture, and a major knowledge gap exists in parsing the relative roles of autogenic versus allogenic processes. Emerging theoretical and experimental work suggests that backwater hydrodynamics play an important role in driving transient channel incision in river deltas, even those experiencing net aggradation. Here, we identify and quantify two autogenic mechanisms that produce broad erosional surfaces in fluvio-deltaic stratigraphy, namely, floods and avulsions. Using a simple mass-balance model for single-threaded delta channel systems, we show that flood-induced scours begin near the shoreline, and avulsion-induced scours begin at the avulsion site, and both propagate upstream over a distance that scales with the backwater length, bed slope, and bed grain size. We also develop scaling relationships for the maximum scour depths arising from these mechanisms, which are functions of characteristic flow depth and formative flood variability. We test our theoretical predictions using a flume experiment of river delta evolution governed by persistent backwater hydrodynamics under constant relative sea level. Results indicate that autogenic dynamics of backwater-mediated deltas under conditions of constant base level can result in stratigraphic surfaces and shoreline trajectories similar to those often interpreted to represent multiple sea-level cycles. Our work provides a quantitative framework to decouple autogenic and allogenic controls on erosional surfaces preserved in fluvio-deltaic stratigraphy.
\end{abstract}

\section{INTRODUCTION}

Major erosional unconformities that separate genetically related sedimentary packages are common in fluvio-deltaic stratigraphy (Van Wagoner et al. 1987; Paola 2000; Catuneanu and Zecchin 2013; Ainsworth et al. 2017). Erosional surfaces are important for characterizing the architecture of sedimentary stratigraphy, and the controls on their formation are often interpreted in terms of allogenic changes in relative sea level, climate, and tectonics (Kraus and Middleton 1987; Van Wagoner et al. 1987; Bromley 1991; Miall and Arush 2001; Adams and Bhattacharya 2005; Bhattacharya 2011). For example, relative sea-level fall is thought to result in extensive erosion and formation of incised valleys, which are subsequently filled during relative sea-level rise and highstand (Van Wagoner et al. 1987, 1990; Posamentier and Vail 1988; Posamentier et al. 1988). Similarly, widespread erosion can result within fluvio-deltaic systems owing to climate-controlled changes in sediment supply in the hinterland (Blum and Törnqvist 2000; Blum et al. 2013). In addition, shoreline trajectories preserved in fluvio-deltaic stratigraphy provide a complementary record of scour surfaces, and form the basis for sequence stratigraphy and seismic stratigraphy (e.g., Helland-Hansen and Martinsen 1996). Trends in shoreline trajectories are classically interpreted solely in terms of allogenic changes (e.g., Helland-Hansen and Martinsen 1996).
In contrast to longstanding stratigraphic models that rely on allogenic forcing, several studies have highlighted the importance of intrinsic dynamics of sedimentary systems (autogenic dynamics), which can mask or override stratigraphic signals of allogenic changes (Best and Ashworth 1997; Strong and Paola 2008; Jerolmack and Paola 2010; Blum et al. 2013; Catuneanu and Zecchin 2013; Ganti et al. 2014b; Mikeš et al. 2015; Hampson 2016; Li et al. 2016; Foreman and Straub 2017; Hajek and Straub 2017; Trower et al. 2018). Despite these advances, little work has focused on autogenic mechanisms for generating broad erosional surfaces on lowland river deltas. Previous work identified scour related to riverbend migration and to river confluences as mechanisms that can generate autogenic erosional surfaces (e.g., Salter 1993; Best and Ashworth 1997), both of which may operate on lowland deltas. Autogenic erosional surfaces on deltas can also occur due to channel shortening and steepening of river beds following avulsion (Jones and Schumm 1999; Slingerland and Smith 2004; Aslan et al. 2005; Dalman et al. 2015; Ganti et al. 2016b). However, most experimental and numerical modeling efforts focused on steep fan deltas, rather than lowland deltas. For example, previous work identified the relative roles of autogenic processes (channel mobility and avulsions) and imposed base-level cycles in determining several attributes of fluviodeltaic stratigraphy such as stratigraphically reconstructed sedimentation rates, shoreline migration rates, scale of parasequences, and variability in preserved bed thickness (e.g., Kim et al. 2006, 2014; Karamitopoulos et al. 
2014; Dalman et al. 2015; Li et al. 2016; Foreman and Straub 2017; Yu et al. 2017). In contrast to fan deltas, morphodynamics of lowland river deltas are strongly influenced by backwater hydrodynamics, which have only recently been investigated in the context of fluvio-deltaic stratigraphy (Chatanantavet et al. 2012; Lamb et al. 2012; Blum et al. 2013; Colombera et al. 2016; Fernandes et al. 2016; Ganti et al. 2016b; Durkin et al. 2017; Martin et al. 2018; Trower et al. 2018).

Backwater hydrodynamics refers to a zone of non-uniform flow that is common in low-gradient coastal rivers and results from subcritical Froude numbers and a relatively fixed water-surface elevation at the river mouth over flood timescales (Lamb et al. 2012; Nittrouer et al. 2012). Lamb et al. (2012) showed that the channels in many river-dominated deltas are within the so-called backwater zone, where large floods drive an upstream wave of bed incision that starts at the river mouth (Lane 1957; Chatanantavet et al. 2012). Flood-induced scours in backwater zones have been reproduced in flume experiments (Chatanantavet and Lamb 2014; Ganti et al. 2016a, $2016 \mathrm{~b}$ ), proposed as an explanation for erosion in the lower $\sim 100 \mathrm{~km}$ of the Mississippi River (Lamb et al. 2012; Nittrouer et al. 2012), and suggested to be a mechanism that can produce large, autogenic erosional surfaces in the stratigraphic record (Lamb et al. 2012; Trower et al. 2018). In addition to erosion during floods, backwater hydrodynamics also exerts a strong control on the location of lobe-scale avulsions on deltas (Chatanantavet et al. 2012; Ganti et al. 2014a, 2016a, 2016b; Chadwick et al. 2019), and therefore should influence the size of erosional surfaces due to channel incision following avulsion. Trower et al. (2018) analyzed the Upper Cretaceous Castlegate Sandstone - a type locality upon which ideas of sequence stratigraphy in fluvio-deltaic settings were developed (Van Wagoner 1991, 1995) - and argued that the scour surfaces previously interpreted as sequence boundaries caused by sea-level fall were consistent with predictions of backwater-induced erosional surfaces.

Thus, there are at least two backwater-influenced mechanisms that might drive autogenic erosional scour on low-gradient river deltas under constant allogenic conditions: a) river-bed incision during floods in the backwater zone, and b) channel incision due to river shortening following avulsions. These two mechanisms are expected to have a stratigraphic expression because the largest floods scour deeply and infrequently, and lobe-scale avulsions reoccur on centennial to millennial timescales, allowing time for scour surfaces to be later buried and preserved through subsidence and compaction. Together, these autogenic mechanisms may result in stacked channel bodies bounded by erosional surfaces and non-monotonic shoreline trajectories even in the absence of allogenic changes. However, we currently lack quantitative metrics for predicting the length and depth scales over which these erosional scours occur on backwater-mediated deltas.

Here, we draw upon recent advances in our understanding of backwatermediated deltaic evolution to propose scaling relationships for the depth and streamwise length of erosional scours driven by floods and avulsions. We compare our theory to new observations from a recent flume experiment, which produced a lobate, avulsing delta controlled by persistent backwater hydrodynamics under constant boundary conditions (Ganti et al. 2016a, 2016b), including shoreline trajectories preserved in stratigraphy. Finally, we explore the implications of our findings for interpreting fluvio-deltaic stratigraphic architecture.

\section{THEORY}

\section{Autogenic Scour Depths}

In this section, we develop theory for the expected depth and length scales of erosional surfaces resulting from floods and avulsions on backwater-mediated deltas under net depositional conditions. To simplify the theory, we focus on a single-threaded coastal river with persistent backwater hydrodynamics, although the framework can likely be extended
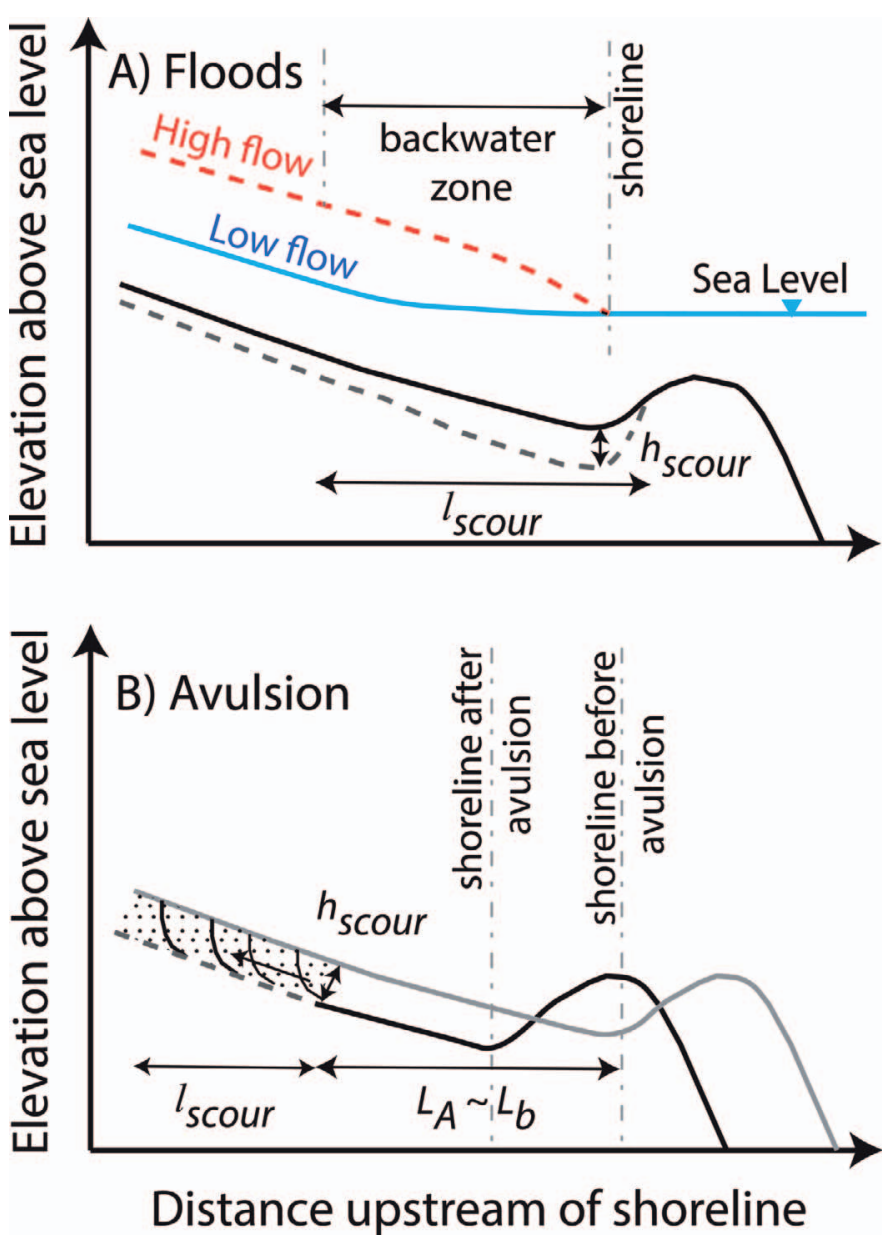

FIG. 1.-Schematic summary of backwater hydrodynamics and the hypothesized autogenic mechanisms that result in erosional scours on backwater-mediated deltas. A) Bed and water-surface elevation profiles under variable flows and steady relative sea level. During high flow (red dashed line indicates water-surface elevation), the constant-sea-level boundary condition results in flow acceleration that causes channel-bed incision in the backwater reach. The solid black line and the dashed gray line indicate width-averaged bed elevation before and after the scour driven by floods, respectively. Flood-induced scours are expected to be maximum near the shoreline and decay with upstream distance. B) The gray and black lines indicate width-averaged bed elevation just before and after an avulsion, respectively. Avulsions can cause river shortening that is hypothesized to result in propagation of erosional scours that start at the avulsion site (denoted here by the successive curved black lines), and may result in erosional surfaces (dashed gray line).

to multi-thread and bifurcating rivers. The length scale over which nonuniform flows extend in the backwater zone is a function of the Froude number, and the difference between the normal flow depth upstream of the backwater zone and the flow depth at the river mouth (Lamb et al. 2012). This length scale can be approximated to first order as $L_{b}=h_{c} / S$ (Paola and Mohrig 1996; Paola 2000), where $h_{c}$ is the characteristic flow depth, which is the bankfull flow depth under normal flow conditions, $S$ is the reachaveraged bed slope, and $L_{b}$ is the characteristic backwater length scale. During large floods with normal flow depths larger than the depth at the river mouth, backwater hydrodynamics cause flow acceleration and sediment erosion in the lower part of the backwater reach (Lane 1957; Lamb et al. 2012) (Fig. 1A). Numerical (Chatanantavet et al. 2012; Lamb et al. 2012) and experimental (Chatanantavet and Lamb 2014; Ganti et al. 2016a, 2016b) work indicate that the depth of channel incision driven by floods is maximum at the river mouth, and this erosion occurs until the 
discharge changes or the river depth is adjusted everywhere to the normal flow depth for a given flood discharge. Chatanantavet and Lamb (2014) and Trower et al. (2018) proposed that the maximum vertical depth of erosion induced by floods, which occur near the river mouth, scales as (Fig. 1A):

$$
h_{\text {scour }} \propto \Delta h
$$

where $h_{\text {scour }}$ is the depth of the erosional scour and $\Delta h$ is the difference between normal flow depths of typical low and high flows that a river experiences over time. The hypothesis given by Equation 1 is based on the theoretical expectation that river stage height is relatively fixed in the backwater zone such that flood discharge variability causes changes in bed elevation through erosion and deposition (Lamb et al. 2012). Ganti et al. (2014a) compiled monthly water-discharge data and computed the normalflow depths for rivers upstream of their backwater zone, and showed that variability in normal-flow depths $(\Delta h)$ scales linearly with the characteristic flow depth, $h_{c}$. They found that $\Delta h$ ranged from $0.5 h_{c}$ to $3 h_{c}$, consistent with field compilations of the ratio of maximum to mean flow depth for modern rivers, which ranges from 1.1 to 5 (Gibling 2006). Thus, we expect the flood-induced scour depths to scale within a small multiple of the characteristic flow depth. Equation 1 has been confirmed using 1-D flume experiments and numerical models on backwater-mediated coastal rivers (Chatanantavet et al. 2012; Chatanantavet and Lamb 2014), but it has yet to be evaluated on a 3-D lobate delta built through avulsion cycles.

In addition to floods, erosional surfaces can also be generated following avulsion due to river shortening (Slingerland and Smith 2004; Aslan et al. 2005; Edmonds 2012; Ganti et al. 2016b). Avulsions are set up by inchannel deposition that renders the channel unstable (Jones and Schumm 1999; Mohrig et al. 2000; Slingerland and Smith 2004). The critical amount of in-channel sedimentation, $h_{\text {fill }}$, required to initiate an avulsion is thought to be proportional to the characteristic flow depth. Therefore, a dimensionless avulsion threshold, $h^{*}$, can be defined as (Ganti et al. 2016b):

$$
h^{*}=h_{\text {fill }} / h_{c}
$$

Field observations (Jerolmack and Mohrig 2007; Jerolmack 2009; Ganti et al. 2014a), outcrop analysis (Mohrig et al. 2000), and laboratory experiments (Ganti et al. 2016b) suggest that $h^{*}$ is the order of unity. Once an avulsion is triggered, rivers often follow a shorter and steeper path (Slingerland and Smith 2004; Aslan et al. 2005; Edmonds 2012; Ganti et al. 2016b). The channel bed elevation just upstream of the avulsion site is expected to be higher than just downstream in the new channel by $h_{\text {fill }}$, which should result in a topographic step (Fig. 1B). We propose that this topographic step in the riverbed can propagate upstream of the avulsion site, resulting in an erosional surface. Avulsion-induced scours are likely to be maximized near the avulsion site, and the vertical depth of erosion should scale with the critical in-channel sedimentation required to trigger an avulsion, i.e.,

$$
h_{\text {scour }} \propto h_{\text {fill }}=h^{*} h_{c}
$$

Thus, similar to flood-induced scours, avulsion-induced scour depths are likely to scale with the characteristic flow depth. Previous experiments have documented autogenic cycles of aggradation and channel incision driven by avulsions on river deltas, alluvial fans, and fan deltas (van Dijk et al. 2009, 2012; Hamilton et al. 2013; Ganti et al. 2016b), although direct measurements of avulsion-induced scour depths and evaluations of Equation 3 have yet to be conducted.

\section{Autogenic Scour Lengths}

Here we derive the streamwise length scales of autogenic erosional scours resulting from floods and avulsions by approximating the temporal evolution of the channel-bed elevation using a diffusion-equation approach to mass balance in one dimension (Paola et al. 1992; Métivier 1999; Paola 2000; Castelltort and Van Den Driessche 2003):

$$
\frac{d \eta}{d t}=\frac{d}{d x}\left(\frac{q_{s}}{S} \frac{d \eta}{d x}\right)
$$

where $\eta$ is the channel-bed elevation, $t$ is time, $q_{s}$ is the volumetric sediment flux per unit channel width, $S$ is the channel-bed slope, and $x$ is the streamwise coordinate. Because $S=-d \eta / d x$, Equation 4 is a 1-D Exner equation for sediment mass balance with constant river width, and $\kappa$ $=q_{s} / S$ can be thought of as diffusivity.

The length scale of propagation of a wave in a diffusive system depends on the diffusivity and the duration of the perturbation, and we estimate the length scale of autogenic erosional scours, $l_{\text {scour }}$, using the following relation:

$$
l_{\text {scour }} \propto \sqrt{\kappa t_{\text {scour }}}
$$

where $t_{\text {scour }}$ is the timescale of the event (e.g., a flood or avulsion cycle) that induces riverbed incision. For erosional events driven by backwater hydrodynamics on deltas, it is convenient to nondimensionalize $l_{\text {scour }}$ with the backwater length $\left(L_{b}\right)$, which results in

$$
\frac{l_{\text {scour }}}{L_{b}}=\sqrt{\frac{t_{\text {scour }}}{t_{\text {adj }}}}
$$

in which

$$
t_{a d j}=\frac{L_{b}^{2}}{\kappa}=\frac{S L_{b}^{2}}{q_{s}}=\frac{h_{c} L_{b}}{q_{s}}
$$

where $t_{a d j}$ is the characteristic bed-adjustment timescale for morphodynamics in the backwater zone, defined by Chatanantavet and Lamb (2014), which is the time to aggrade the backwater zone by one channel depth. To derive Equation 6 from Equation 5, we replaced the diffusivity with the bed-adjustment timescale through Equation 7. Equations 6 and 7 provide a framework for predicting the length scale of autogenic erosional scours on backwater-mediated deltas for floods and avulsions if the sediment flux, $q_{s}$, can be estimated, which we discuss next.

For floods, we estimate the volumetric sediment flux on the flood timescale using a relation for total bed-material transport rate for sandbedded rivers (Engelund and Hansen 1967):

$$
q_{s}=\left(\operatorname{Rg} D_{50}^{3}\right)^{1 / 2}\left(\frac{0.05}{C_{f}}\right) \tau_{*}^{5 / 2}
$$

in which $R$ is submerged specific density of sediment ( $\approx 1.65$ for quartz), $D_{50}$ is the median bed-material grain size, $C_{f}$ is the bed friction coefficient (assumed to be 0.002 , which is a typical value for large lowland rivers (Parker et al. 2007), and $\tau^{*}$ is the Shields number (Shields 1936) given by

$$
\tau^{*}=\frac{h_{n} S}{R D_{50}}
$$

under normal flow conditions where $h_{n}$ is the normal flow depth of a given flood event. Replacing $q_{s}$ in Equation 7 with the expression in Equation 8, and substituting Equation 9 in Equation 6 results in an analytical prediction for the dimensionless flood-induced scour length given by

$$
\frac{l_{\text {scour }}}{L_{b}}=\left[\frac{0.05}{C_{f}} \frac{g^{1 / 2} h_{n}^{5 / 2} S^{7 / 2}}{R^{2} h_{c}^{2} D_{50}} t_{\text {scour }}\right]^{1 / 2}
$$

Given that the ratio of the maximum to mean flow depths ranges from 1.1 to 5 in many rivers (Gibling 2006), we can approximate $h_{n} \approx 3 h_{c}$ in Equation 10 to estimate the dimensionless length scale of flood-induced scours. The timescale of the scour event, $t_{\text {scour }}$, is equal to the flood duration, which typically ranges from a few days to months. 
For avulsions, we do not use Equation 8 because we must average over many flood events for avulsion timescales. Instead, we develop relations for $q_{s}$ based on mass balance over a complete avulsion cycle that has a characteristic reoccurrence time of $t_{A}$. Following previous work (Paola 2000; Ganti et al. 2014a; Reitz et al. 2015), we assume for simplicity a river-dominated delta with no reworking by waves and tides, constant riverbed slope, $S$, and a vertical delta foreset (Fig. 2). The total input fluvial sediment volume per unit width over the avulsion timescale, i.e., $q_{s} t_{A}$, is balanced between delta-topset deposition and delta-foreset deposition that results in delta-lobe progradation (Fig. 2). Both delta-lobe progradation and relative sea-level change result in aggradation of the riverbed, and we assume that at the time of an avulsion the total amount of channel-bed aggradation is equal to the critical in-channel sedimentation that triggers an avulsion, i.e., $h_{\text {fill }}$ (Fig. 2).

Based on these considerations, Ganti et al. (2014a) proposed that the length of progradation during an avulsion cycle, $D_{p}$, before abandonment via an avulsion is

$$
D_{p}=L_{b}\left(h^{*}-z / h_{c}\right)
$$

where $z$ is the amount of relative sea-level rise (or fall) (Fig. 2B, C), which can be written as

$$
z=n \sigma t_{A}
$$

in which $\sigma$ is the relative sea-level rise (or fall) rate averaged over $t_{A}$, and $n$ is the number of avulsions that typically occur before a given lobe is reoccupied. For example, if lateral lobe switching is random amongst the topographic lows, then $n$ can be approximated as

$$
n=(N+1) / 2
$$

where $N$ is the total number of lobes that are tied to a given avulsion node (Fig. 2D)

Next, we assume that the avulsion length, $L_{A}$, which is the streamwise distance between the river mouth and the avulsion site, remains constant and scales with the backwater length (Fig. 2A) (Chatanantavet et al. 2012; Ganti et al. 2014a, 2016a, 2016b; Chadwick et al. 2019). The avulsion site is likely to stay relatively fixed until the lobes laterally fill the space owing to the tendency for compensational stacking (Straub et al. 2009). For example, as shown in Figure 2D, with steady relative sea level, the avulsion site is conceptualized to stay spatially fixed as delta lobes 1 through 5 are built. Once the river avulses from the active lobe to space 5, all lateral accommodation will be filled and the river will be forced to prograde and the avulsion site is likely to translate downstream (Ganti et al. 2014a, 2016a). In our conceptual framework, the river aggrades by $h_{\text {fil }}$ during the construction of the first lobe at a given avulsion site (e.g., lobe 1 in Fig. 2D), and following a lateral avulsion, the new channel for successive lateral lobes (e.g., lobes 2 to 5) will initially be steeper than the equilibrium bed slope because of river shortening. Thus, the trunk channel upstream of the avulsion site can experience repeated cycles of incision and fill during the construction of lateral lobes.

Given the framework proposed for lobe construction and avulsion in Figure 2, we equate the total input sediment volume during $t_{A}$ to the total amount of sediment deposited on the delta topset and foreset during an avulsion cycle (Figs. 2A-C), yielding:

$$
\begin{gathered}
q_{s} t_{A}=\left(L_{A}-D_{p}\right) h_{\text {fill }}+D_{p}\left(D_{p} S / 2+B+n \sigma t_{A}\right), D_{p}>0 \\
q_{s} t_{A}=L_{A} h_{\text {fill }}, D_{p} \leqslant 0
\end{gathered}
$$

in which $B$ is the basin depth. The first term in the right-hand side of Equation 14a accounts for deposition on the delta topset, and the second term accounts for deposition on the foreset during delta-lobe progradation (Fig. 2). For a regressive shoreline, i.e., $D_{p}<0$, only delta topset sedimentation is needed for mass balance (Equation 14b).
For avulsion-induced scours, the erosional wave can propagate for the entire avulsion cycle; thus, we set $t_{\text {scour }}=t_{A}$ in Equation 6, and therefore $l_{\text {scour }} / L_{b}=\sqrt{t_{A}^{*}}$, where $t_{A}^{*}=t_{A} / t_{\text {adj }}$ is a dimensionless avulsion timescale (Ganti et al. 2014a). We cast Equation 14 in terms of $t_{A}^{*}$ by combining Equations 2, 7, and 11 through 14 . We nondimensionlize the resulting equation to yield

$$
t_{A}^{*}=\frac{-\left(1+n B^{*} \sigma^{*}-n \sigma^{*} h^{*}\right)+\sqrt{\left(1+n B^{*} \sigma^{*}-n \sigma^{*} h^{*}\right)^{2}-n^{2} \sigma^{* 2} h^{*}\left(h^{*}-2 L_{A}^{*}-2 B^{*}\right)}}{n^{2} \sigma^{* 2}}, D_{p}>0
$$

$$
t_{A}^{*}=L_{A}^{*} h^{*}, D_{p} \leqslant 0
$$

in which $\sigma^{*}=\sigma L_{b} / q_{s}$ is a dimensionless relative sea-level rise rate that will be $\sim 1$ when the relative sea-level rise rate matches the rate of aggradation on the delta topset with no progradation; $B^{*}=B / h_{c}$ is the basin depth normalized by the characteristic flow depth; and $L_{A}^{*}={ }^{*} L_{A} / L_{b}$ is the avulsion length normalized by the backwater length, which is approximately unity for many river-dominated deltas (Jerolmack and Swenson 2007; Chatanantavet et al. 2012; Ganti et al. 2014a, 2016a; Chadwick et al. 2019). Thus, autogenic scour length, $l_{\text {scour }}$, can be estimated by combining Equations 15 and 6. Under the simplifying case of $\sigma=0$, Equation 15 reduces to

$$
\begin{gathered}
t_{A}^{*}=h^{*}\left(L_{A}^{*}+B^{*}-h^{*} / 2\right), D_{p}>0 \\
t_{A}^{*}=L_{A}^{*} h^{*}, D_{p} \leqslant 0
\end{gathered}
$$

We note that some parameter ranges can violate model assumptions. We are able to constrain mass balance over an avulsion timescale only for a net aggradational delta that undergoes avulsions. Thus, the rate of relative sealevel rise between successive avulsions (Equation 12) cannot result in shoreline transgression across the backwater zone that is faster than bed aggradation to the point of avulsion, i.e.,

$$
n \sigma^{*} \leqslant 1 / h^{*}
$$

In addition, the amount of sea-level fall during an avulsion cycle cannot exceed the basin depth,

$$
\sigma^{*} \leqslant-B^{*} / n t_{A}^{*}
$$

Combining Equations 18 and 15 yields

$$
n \sigma^{*} \leqslant \frac{-2 B^{*}}{h^{*}\left(2 L_{A}^{*}+2 B^{*}-h^{*}\right)+B^{* 2}-2 B^{*} h^{*}}
$$

In the following sections, we test the proposed theory using experimental data from a delta that evolved under persistent backwater hydrodynamics and through deposition of many lobes under constant relative sea level, with sediment supply equal to the sediment transport capacity (Ganti et al. 2016a, 2016b). This experiment provides an ideal test case for investigating erosional scours arising from floods and avulsions in the absence of allogenic changes. In the next section, we summarize the experimental arrangement and data collected and then the methods used for extracting the erosional scour depths and lengths from the experimental data.

\section{METHODS}

\section{Experimental Methods and Delta Evolution}

The experiments presented here were first reported by Ganti et al. (2016a, 2016b). The experimental facility consisted of an alluvial river, 7 $\mathrm{cm}$ wide and $7 \mathrm{~m}$ long, that drained into an ocean basin, $5 \mathrm{~m}$ long, $3 \mathrm{~m}$ wide, and $0.1 \mathrm{~m}$ deep (Fig. 3). Sediment and water were fed at the upstream end of the flume and the sea level was held constant using a programmable standpipe at the end of the ocean basin (Fig. 3). Crushed 

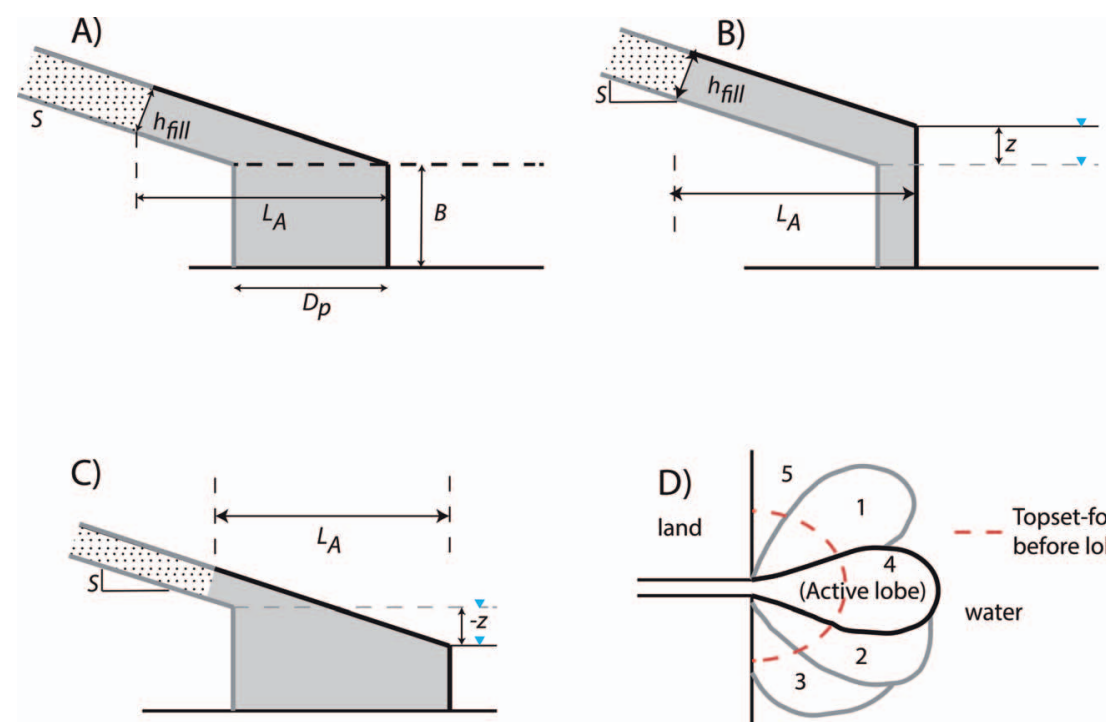

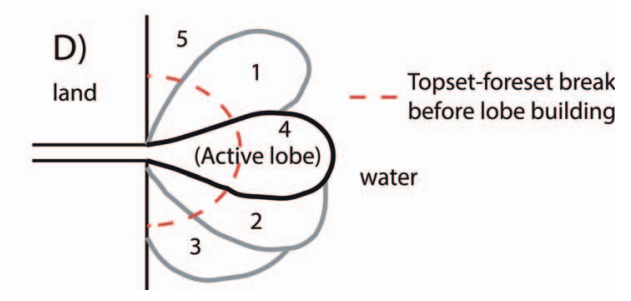

FIG. 2.- Schematic illustration of the massbalance framework used in this study for estimating the length scale of autogenic avulsioninduced scours in the case of net aggradational avulsion cycles for A) steady relative sea level, B) relative sea-level rise, and $\mathbf{C}$ ) relative sea-level fall. The solid lines indicate the simplified long profiles of a delta lobe with a constant slope, $S$, and a vertical foreset draining into a basin of depth $B$ under steady relative sea level (dashed line). The solid gray and black lines indicate bed elevation at the beginning and end of an avulsion cycle, respectively. During the time between successive avulsions $\left(t_{A}\right)$, the total fluvial input sediment volume is partitioned between delta topset deposition and delta foreset deposition, which results in delta progradation by a length scale of $D_{p}$. The shaded gray area indicates the sediment volume deposited during an avulsion cycle. The avulsion length, $L_{A}$, is assumed to be constant in all cases, and scales with $L_{b}$. Avulsions are hypothesized to occur when the riverbed aggradation is equal to the critical amount of inchannel sedimentation needed to trigger an avulsion, $h_{\text {fill }}$. D) Schematic of planview evolution of backwater-mediated deltas under constant relative sea level. In this example, the avulsion node is conceptualized to stay spatially fixed as the delta lobes 1 through 5 are built. Once the lateral accommodation space indicated by " 5 " is filled, the avulsion sites are likely to translate downstream with shoreline progradation. The dashed red line indicates the delta topset-foreset break before lobe building tied to a given avulsion site. walnut shells of uniform grain size $\left(D_{50}=0.7 \mathrm{~mm}, \rho_{s}=1300 \mathrm{~kg} / \mathrm{m}^{3}\right)$ were used as the sediment, which resulted in a single-thread channel with subcritical flows and shallow riverbed slopes that are typical of natural lowland rivers (Table 1). To achieve persistent backwater hydrodynamics, which has been argued to be necessary to develop avulsion locations that scale with the backwater length like natural lowland deltas (Chatanantavet et al. 2012; Chadwick et al. 2019), Ganti et al. (2016a, 2016b) oscillated the water discharge between a $40 \mathrm{~min}$ low flow (water discharge, $Q_{w}=8.3$ $1 / \mathrm{min}$; normal flow depth, $h_{n}=9.5 \mathrm{~mm}$; normal flow Froude number, $\mathrm{Fr}=$ $0.67)$ and $15 \mathrm{~min}$ high flow $\left(Q_{w}=121 / \mathrm{min} ; h_{n}=13 \mathrm{~mm} ; \mathrm{Fr}=0.63\right)$ for $\sim 150 \mathrm{hrs}$. Using a quasi-2D morphodynamic model as a guide (Chatanantavet and Lamb 2014), the sediment supply was set to the sediment-transport capacity of each of these flows for normal flow conditions (sediment feed rate for low and high flows were $36 \mathrm{~g} / \mathrm{min}$ and $60 \mathrm{~g} / \mathrm{min}$, respectively) such that erosion during high flows was not forced due to an imbalance between sediment supply and water discharge. The duration of each flow was chosen to be short enough that the riverbed in the backwater zone was in a state of perpetual transient adjustment, which is necessary for persistent backwater hydrodynamics during delta growth (Chatanantavet and Lamb 2014). The characteristic backwater length scale using $L_{b}=h_{c} / S$ was $2.9 \mathrm{~m}$, where $h_{c}=9.5 \mathrm{~mm}$ and $S=3.3 \times 10^{-3}$, which was the measured riverbed slope in the normal-flow reach for both of the flows.

We collected data on water-surface and bed-surface elevation periodically during the experiment using an ultrasound distance meter (Massa) and laser triangulation sensor (Keyence), respectively. For this study, we used the bed-elevation data collected with the laser triangulation sensor at the end of each flow event (i.e., low flow and high flow) after the flow was switched off. The bed-elevation data in the fixed-width part of the experimental facility were collected at a horizontal resolution of $1 \mathrm{~mm}$, and the bed elevation data on the delta topset were collected at a horizontal resolution of $3 \mathrm{~mm}$ by $3 \mathrm{~mm}$. While collecting the bed-elevation data, the basin was not drained and an empirical correction for the refractive index of the Keyence beam through still water was performed (Ganti et al. 2016a, 2016b). The combined instrument error and the empirical correction for the refraction index was $\pm 0.1 \mathrm{~mm}$. The raw data were then denoised using a moving-median filter with a kernel size of $1.5 \mathrm{~cm}$ (Ganti et al. 2016a).

We constructed the synthetic experimental stratigraphy using the topographic elevation time series. We identified the erosional bounding surfaces as the lowest elevation in time such that no future elevation is lower than this given value (see Ganti et al. 2011 and 2013 for an example application of this method). Owing to the lack of grain-size variation in our experiment, we did not take physical stratigraphic cuts at the end of the experiment; however, previous workers have demonstrated good agreement between synthetic and physical stratigraphy in an avulsion-dominated fan system (Straub et al. 2012).

Ganti et al. (2016a, 2016b) documented the growth of the delta (Fig. 3) and the occurrence of 41 avulsions during the $\sim 150 \mathrm{hr}$ of experimental runtime (Fig. 4A). The experimental evolution can be classified into three distinct phases, which are important for isolating the causes of erosional surfaces observed in the experiment. For the first $\sim 13.9 \mathrm{hr}$ of the experimental runtime, no avulsions were observed and the average radial distance of the shoreline from the change in confinement in the experimental facility grew rapidly to $0.5 \mathrm{~m}$ (Ganti et al. 2016b). During the second phase of delta growth, avulsions occurred in the vicinity of the change in confinement in the experimental facility from $13.9 \mathrm{hr}$ to $66 \mathrm{hr}$ of the experimental runtime (Figs. 3, 4A), and the average radial distance of the shoreline from the change in confinement in the experiment increased 


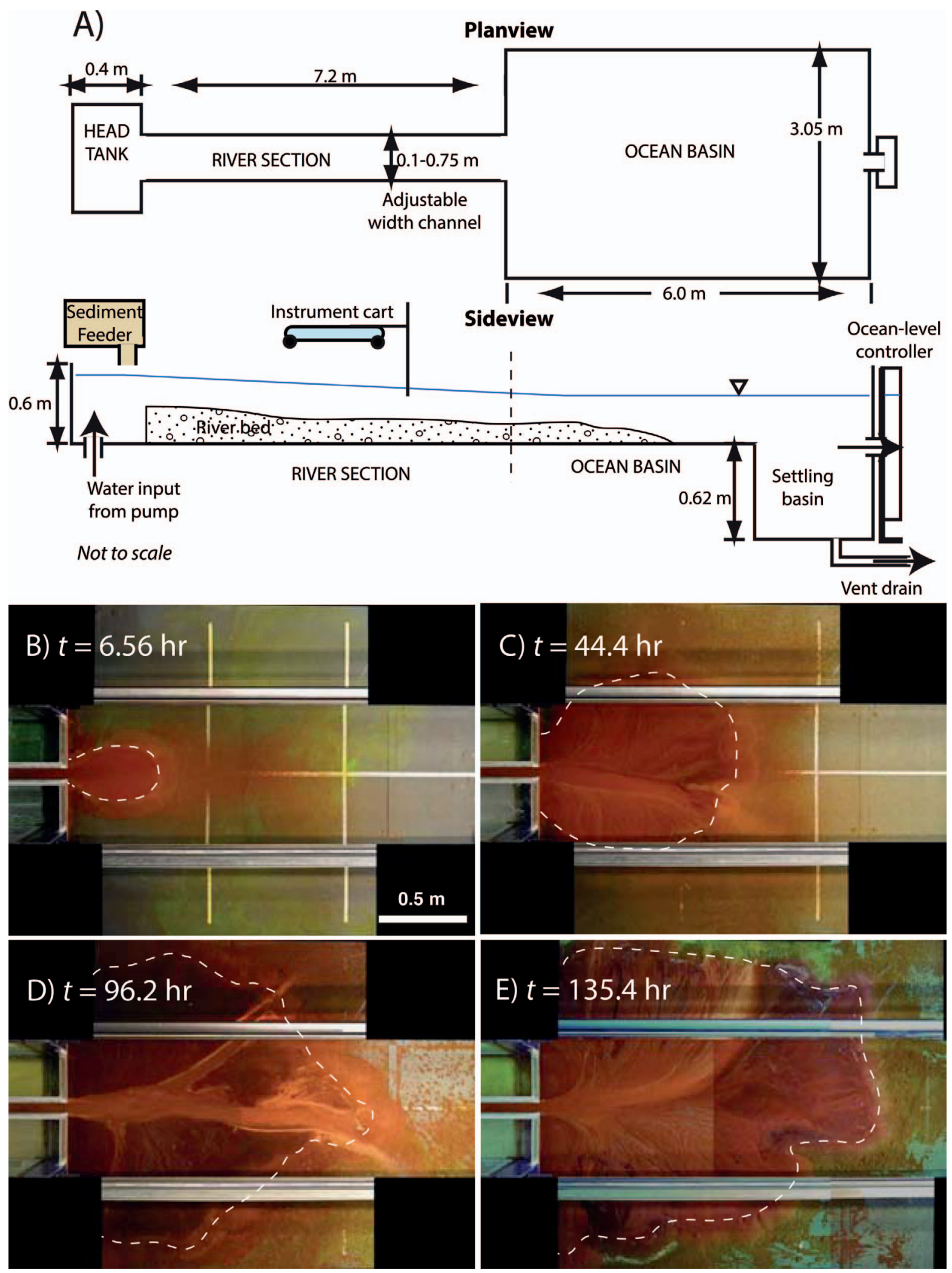

FIg. 3.-Summary of experimental arrangement and deltaic evolution. A) Schematic of the plan view and side view of the experimental arrangement in the Earth Surface Dynamics Laboratory at the California Institute of Technology. Only $5 \mathrm{~m}$ of the longitudinal section of the ocean basin was used by placing a false floor level with the confined part of the experimental facility. B-E) Temporal sequence of the overhead images of the experimental delta. The scale of the pictures is shown in Part B, and the white dashed lines indicate the shorelines. The two silver horizontal bars are instrument rails that sit above the experiment. Figures are reproduced from Ganti et al. (2016b). 
TABLE 1.-Compilation of dimensionless parameters estimated for natural backwater-mediated deltas. The symbols denote the following parameters: $\mathrm{S}$, channel bed slope; $\mathrm{h}_{\mathrm{c}}$, characteristic flow depth; $\mathrm{D}_{50}$, median grain size; $\mathrm{L}_{\mathrm{b}}$, characteristic backwater length scale; $\mathrm{L}_{\mathrm{A}}$, avulsion length; $\mathrm{B}$, basin depth; Fr, Froude number for the characteristic flow depth; $\mathrm{t}_{\mathrm{A}}$, avulsion timescale; $\mathrm{L}_{\mathrm{A}}{ }^{*}$, dimensionless avulsion length; $\mathrm{h}^{*}$, dimensionless avulsion threshold;

$\mathrm{B}^{*}$, dimensionless basin depth; $\sigma^{*}$, dimensionless relative sea-level rise rate.

\begin{tabular}{|c|c|c|c|c|c|c|c|c|c|c|c|c|c|}
\hline River & $\begin{array}{c}S \\
\left(\times 10^{-4}\right)\end{array}$ & $h_{c}[\mathrm{~m}]$ & $D_{50}[\mathrm{~mm}]$ & $L_{b}[\mathrm{~km}]$ & $L_{A}[\mathrm{~km}]$ & $B[\mathrm{~m}]$ & $\operatorname{Fr}[-]$ & $t_{A}[\mathrm{yr}]$ & $L_{A}{ }^{*}[-]$ & $h^{*}[-]^{\S}$ & $B^{*}[-]^{\dagger}$ & $\sigma^{*}$ (rise) $[-]^{\ddagger}$ & $\sigma^{*}$ (fall) $[-]^{+}$ \\
\hline Paraná & 0.4 & 11.8 & 0.3 & 295 & 210 & 40 & 0.14 & 1633 & 0.71 & 0.7 & 3.39 & 0.13 & 0.093 \\
\hline Nile & 0.64 & 16.2 & 0.4 & 254 & 210 & 120 & 0.18 & - & 0.83 & - & 7.41 & 0.014 & 0.0099 \\
\hline Lower Mississippi & 0.43 & 21 & 0.3 & 480 & 490 & 80 & 0.15 & 1250 & 1.02 & 0.6 & 3.81 & 0.022 & 0.016 \\
\hline Assiniboine & 5 & 5.71 & 0.5 & 8.4 & 12 & $140^{\dagger}$ & 0.50 & 1000 & 1.43 & 0.2 & 24.52 & - & - \\
\hline Rhine-Meuse & 1.1 & 5 & 0.5 & 45.5 & 51 & $140^{\dagger}$ & 0.23 & 1450 & 1.12 & 0.4 & 28.00 & 0.095 & 0.0626 \\
\hline $\begin{array}{l}\text { Mid. Amazon } \\
\text { (at Negro R.) }\end{array}$ & 0.3 & 12 & 0.25 & 400 & 404 & $140^{\dagger}$ & 0.12 & - & 1.01 & - & 11.67 & 0.027 & 0.02 \\
\hline Upper Rhone & 0.4 & 5.4 & 0.3 & 135.2 & - & 70 & 0.14 & 1450 & - & 0.5 & 12.96 & 0.045 & 0.032 \\
\hline Huanghe & 1 & 3.5 & 0.1 & 35 & 31 & 30 & 0.22 & 7 & 0.89 & 0.4 & 8.57 & 0.00043 & 0.00031 \\
\hline Bramhaputra & 1 & 7 & 0.5 & 70 & - & $140^{\dagger}$ & 0.22 & 500 & - & 1.4 & 20 & 0.012 & 0.0084 \\
\hline Experiment & 33 & $\begin{array}{c}9.5 \\
\times 10^{-3}\end{array}$ & 0.7 & $\begin{array}{c}2.9 \\
\times 10^{-3}\end{array}$ & $\begin{array}{c}1.3 \pm 0.3 \\
\times 10^{-3}\end{array}$ & 0.1 & 0.67 & $\begin{array}{l}6.7 \pm 4 \\
\times 10^{-4}\end{array}$ & $\begin{array}{l}0.45 \\
\pm 0.1\end{array}$ & $\begin{array}{c}0.3 \\
\pm 0.13\end{array}$ & 10.5 & 0 & 0 \\
\hline
\end{tabular}

Slope, characteristic flow depth, avulsion length, backwater length, and avulsion timescale are compiled from Chatanantavet et al. (2012), Chatanantavet and Lamb (2014), Ganti et al. (2014a), Jerolmack and Mohrig (2007a), and Jerolmack (2009).

${ }^{\dagger}$ Basin depths were equated to the water depth reached by subaqueous clinoforms reported in Syvitski and Saito (2007). Where data were unavailable, we assumed the basin depth to be $140 \mathrm{~m}$, which is the estimated average shelf break depth (Gross 1977).

$\$$ The dimensionless relative sea-level rise and fall rates reported here were computed by using the averages of rates of relative sea-level change over the last $1 \mathrm{Ma}$ (Bintanja et al. 2005), and the sediment flux estimates reported in Milliman and Syvitski (1992) and Middelkoop et al. (2010).

$\S$ Dimensionless avulsion threshold was equated to the ratio of the measured avulsion timescale to the characteristic channel-filling timescale. This ratio was argued to scale with the dimensionless avulsion threshold (Ganti et al. 2014a, 2016b).

to $\sim 0.9 \mathrm{~m}$ (Ganti et al. 2016b), which was smaller than the backwater length. Of the 41 documented avulsions, 29 occurred during this second phase of delta growth, when the delta was too small to allow backwaterscaled avulsions. In the final stage of the deltaic evolution $(t>66 \mathrm{hr})$, the delta grew large enough (the average radial distance of the shoreline from the change in confinement was $>1 \mathrm{~m}$ ) such that $>0.5 L_{b}$ of the downstream part of the experimental river was within the ocean basin (Fig. 3 ). During this phase, the avulsion length $\left(L_{A}\right)$ scaled with the backwater length and the avulsion locations translated seaward with shoreline progradation (Fig. 4A), consistent with theoretical expectations (Ganti et al. 2014a).

\section{Data Analysis to Identify Autogenic Scour Mechanisms}

We used the three different phases of the experimental growth to isolate the mechanisms of autogenic scours. We isolated the flood-induced scours by focusing our analyses on the first phase of experimental evolution of the delta before avulsions occurred. During this time $(t<13.9 \mathrm{hr}), 14$ flood cycles occurred. This procedure allows an objective definition of the length and depth scales of flood-induced scours in the absence of competing effects from avulsion-induced scours; this is particularly important in defining the length scales over which flood-induced scours propagate. In contrast to the flood-induced scours, we isolated the backwater-mediated avulsion-induced scours by focusing our analyses on phase 3 , when the experimental delta grew through repeated backwater-mediated avulsion cycles, i.e., $t>66 \mathrm{hr}$. For the 12 avulsions documented during phase 3 , shortening of river length following an avulsion was observed in nine cases (Ganti et al. 2016b). We compiled the avulsion-induced scour depths for six of these avulsion cycles, and excluded three avulsion cycles from our analysis because they had $t_{A}<2 \mathrm{hr}$, i.e., avulsions occurred in successive flood cycles, which limited the temporal resolution of bed-topography measurements relative to $t_{A}$.
We analyzed the channel-width-averaged long profiles of active channels through the experimental runtime to estimate scour depths. We measured the long profiles in the fixed-width part of the experiment directly at the end of each high or low flow event. On the delta topset, we extracted the cross-sectional topography perpendicular to the channel thalweg, and the channel-width-averaged bed elevation was estimated as the difference between the average elevation of the channel levees and the ratio of the channel cross-sectional area to channel width (Ganti et al. 2016a, 2016b). The channel-width-averaged bed elevation from the delta topset and the confined part of the experiment were then stitched together to yield the long profiles of the active channels at the end of each flow event. We estimated the flood-induced scours as the difference between the channel-width-averaged bed elevation at the end of a low-flow event and the long profile at the end of the subsequent high-flow event for phase 1 of the experiment. We computed avulsion-induced scours by differencing the channel-width-averaged bed elevation at the end of the avulsion cycle and the lowest channel-width-averaged bed elevation that occurred at any time during the same avulsion cycle. We assigned an erosional scour depth of zero when no incision occurred at a given location, i.e., when the bed aggraded continuously through the avulsion cycle. We computed the size of avulsion-induced scours for phase 3 of the experiment.

We measured the length scales of flood-induced and avulsion-induced scours relative to the shoreline and the avulsion site, respectively (Fig. 1). Given the asymptotic nature of decay of erosional scours with upstream distance (Fig. 1), we estimated $l_{\text {scour }}$ as the $e$-folding length of erosional scours, i.e., the streamwise distance between the location of maximum erosional scour and the location where the measured erosional scour depths decreased by a factor of $e(e \approx 2.718)$ relative to the maximum erosional scour depth. This was done to objectively define the length scale of erosional scours in the experiment and to avoid interpreting submillimeterscale fluctuations in topography. 

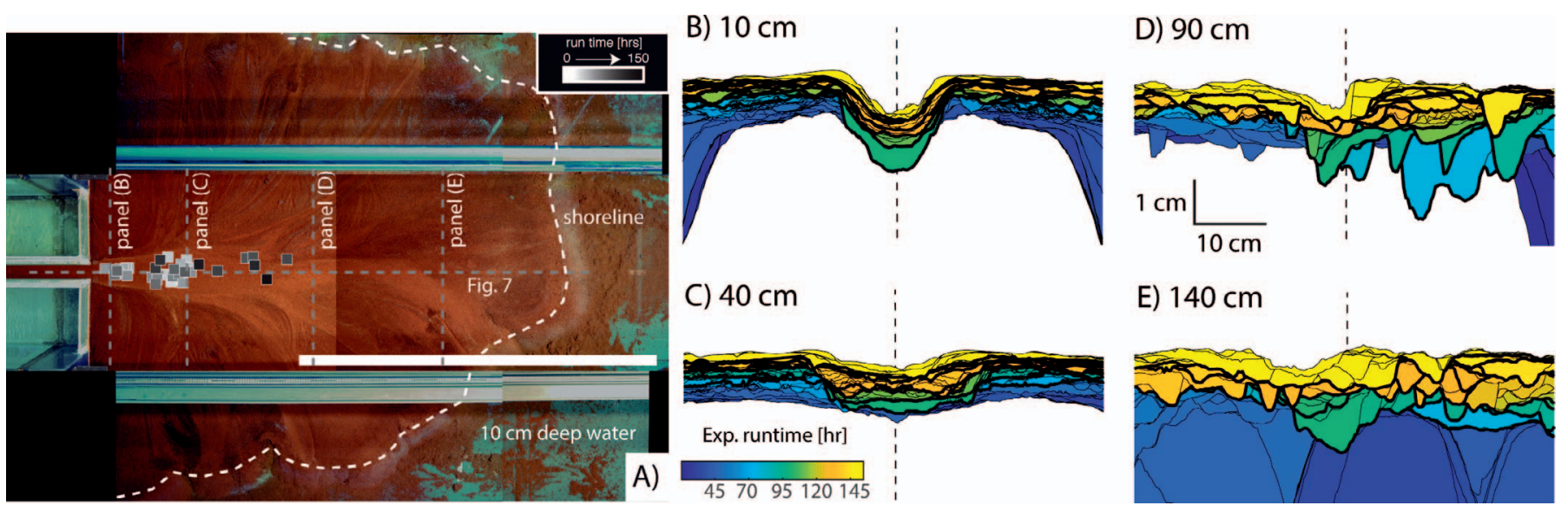

FIG. 4.- Summary of the temporal evolution of the avulsion sites and example synthetic stratigraphic sections. A) Overhead image of the experimental delta taken at the end of the experimental run. The observed avulsion sites are overlaid on this image and are graded from white to black in time, where the seaward translation of the avulsion sites with time is evident. The shoreline is indicated by the white dashed line, and the white scale bar indicates a length of $0.5 L_{b}(1.45 \mathrm{~m})$. The dashed gray lines indicate the locations of the synthetic stratigraphic sections presented (and in Fig. 7B). B-E) Synthetic stratigraphy profiles constructed from elevation time series at four locations at 10, 40, 90, and $140 \mathrm{~cm}$ longitudinal distances measured from the change in confinement in the experimental facility. Parts B and C coincided with the axial plane of avulsion sites during phases 2 and 3 of the experiment, and Parts D and E were downstream of the avulsion sites. The thin black lines denote the bounding surfaces, the color indicates the time of deposition of each sedimentary package, and the dashed lines denote the flume centerline. Successive thick black lines denote the bounding surfaces corresponding to individual backwater-mediated avulsion cycles (phase 3 of the experiment), i.e., the deposit bounded by these surfaces was deposited within a single avulsion cycle.

In addition to quantifying the erosional scours, we analyzed the shoreline trajectories in our experiment, because interpretation of cyclicity produced by shoreline migration is a key element of seismic and sequence stratigraphy (Helland-Hansen and Martinsen 1996). For characterizing shoreline trajectories, we constructed the synthetic stratigraphy in the depositional-dip direction along the flume centerline from the elevation time series as described in the previous subsection. We analyzed the stratigraphic bounding surfaces in this deposit at each time step, and manually picked the delta topset-foreset rollover, which represents the preserved shoreline positions in the stratigraphic record. The crosssectional path of the preserved shoreline positions in the depositional-dip direction describes the experimental shoreline trajectory.

\section{Comparison to Theory, Previous Work, and Natural Deltas}

To compare to theory, we differenced the normal flow depths of low and high flows, which were measured in the first $3 \mathrm{~m}$ of the experimental facility, well upstream of the backwater zone, to quantify the formative flood variability in our experiment (Equation 1). The timescale between successive backwater-mediated avulsions, $t_{A}$, was variable with a mean and standard deviation of $5.86 \pm 3.5 \mathrm{hr}$ (Ganti et al. 2016b). The critical amount of in-channel sedimentation $\left(h_{\text {fill }}\right)$ required to initiate the backwater-mediated avulsions scaled with the characteristic flow depth $\left(h_{c}\right)$, and $h^{*}$ was tightly constrained with a mean and standard deviation of $0.3 \pm 0.13$. The dimensionless experimental basin depth was $B^{*}=10.5$, and the dimensionless relative sea-level rise rate was $\sigma^{*}=0$. The experimental dimensionless parameters were similar to natural examples as described below (Table 1).

To compare with natural deltas, we compiled field data and computed $L_{A}^{*}$ as the ratio of the observed avulsion length to the calculated backwater length and $h^{*}$ was equated to the ratio of the measured avulsion timescale and the characteristic channel-filling timescale (time to aggrade a channel by $h_{c}$ ) (Ganti et al. 2014a, 2016b). The basin depths were compiled from the reported water depths reached by the subaqueous clinoforms (Syvitski and Saito 2007), and where data were unavailable we assumed the basin depth to be equal to $140 \mathrm{~m}$, which represents the average shelf-break depth (Gross 1977). Of the 12 river deltas for which data were compiled (Table
1), we assumed $B=140 \mathrm{~m}$ for four deltas. The estimated $B^{*}$ values for natural deltas with measured values of $B$ span 3 to 33, which supersedes the range of $B^{*}$ values computed for the four river deltas with the assumption of $B=140 \mathrm{~m}$ (Table 1). We estimated $\sigma^{*}$ using the average sealevel rise rates $(3.5 \mathrm{~mm} / \mathrm{yr})$ and fall rates $(2.3 \mathrm{~mm} / \mathrm{yr})$ reconstructed over the last 1 Myr (Bintanja et al. 2005), and using the sediment-flux values reported in Milliman and Syvitski (1992) and Middelkoop et al. (2010) (Table 1).

We also compare the model with depth and length scales of floodinduced scours from the experimental study of Chatanantavet and Lamb (2014). Chatanantavet and Lamb (2014) developed a quasi-2-D morphodynamic numerical model and validated it with flume experiments in a 7.5m-long flume to study the evolution of the channel bed in the backwater zone in response to two different flow discharges. The initial condition for their numerical model and experimental run was the equilibrium bed topography that adjusted to a low flow with normal flow depth of $h_{c}=6.4$ $\pm 0.4 \mathrm{~cm}$ and $S=1.5 \times 10^{-3}$. The low-flow equilibrium bed topography was subjected to a high-flow event with a normal flow depth of $12.3 \pm 0.8$ $\mathrm{cm}$, and the bed slopes in the normal flow reach of low and high flows were equal because the ratio of sediment supply to transport capacity was held constant, similar to our experiments. We computed the flood-induced scours from their flume-calibrated numerical model as the difference between the low-flow equilibrium bed topography and the bed topography at three different times during the high-flow event based on their published results (see Fig. 4D in Chatanantavet and Lamb 2014). The dimensionless flood-induced scour lengths were $l_{\text {scour }} / L_{b}=0.08,0.165$, and 0.4 , and the maximum dimensionless scour depths were $h_{c} / h_{\text {scour }}=0.14,0.24$, and 0.4 at $3 \mathrm{~min}, 13 \mathrm{~min}$, and $103 \mathrm{~min}$, respectively. The erosional scours propagated the entire backwater length and reached a maximum value of $h_{\text {scour }} / h_{c}=0.72$ at equilibrium conditions with the high-flow event. To compare with theory, we predicted $l_{\text {scour }} / L_{b}=0.04,0.08$, and 0.21 for flood-induced scours using Equation 5, where $t_{\text {scour }}=3,13$, and 103 min, and the dimensional diffusivity was $\kappa=0.013 \mathrm{~m}^{2} / \mathrm{s}$ with $S=1.5 \times 10^{-3}$ and $q_{s}=2.0 \times 10^{-5} \mathrm{~m}^{2} / \mathrm{s}$ was the sediment transport capacity during the high-flow event. We also predicted the maximum scour depths using the difference between the reported normal flow depths for the high-flow and low-flow events. 


\section{RESULTS}

The synthetic stratigraphy near the avulsion sites shows erosional surfaces that bound stacked channel deposits in a deeper valley along the flume centerline, and stratigraphy on the flanks of the main channel was created predominantly by crevasse-splay deposits during the final phase of delta evolution (Fig. 4B, C) (Ganti et al. 2016b). In contrast, stratigraphic transects downstream of the avulsion sites comprised superimposed channel bodies bounded by erosional surfaces (Fig. 4D, E), which resulted from the reoccupation of previously channelized locations (Ganti et al. 2016b). Thus, there are numerous erosional bounding surfaces in the synthetic stratigraphic record due to floods and avulsions, despite the experiment being conducted under constant conditions of base level and with constant ratios of sediment supply to transport capacity (Fig. 4). The experimental channels exhibited limited lateral mobility in the backwater zone (Ganti et al. 2016a), similar to lowland coastal rivers (Lamb et al. 2012; Fernandes et al. 2016; Durkin et al. 2017), and were characterized by single-threaded morphology. These observations indicate that river-bend scours and confluence scours had limited roles in creating the observed erosional bounding surfaces.

To further illustrate the role of floods and avulsions on scour surfaces, Figure 5 shows an example lobe-switching event in the experiment along with the dimensionless long profiles of channel-bed elevation immediately after a backwater-mediated avulsion. Experimental observations indicate that channel incision occurred at the avulsion site immediately following the avulsion (orange profile in Fig. 5B), and propagated farther upstream during the next avulsion cycle (blue profile in Fig. 5B). In addition, our data show that channel incision occurred up to a distance of $\sim 0.3 L_{b}$ from the shoreline during a flood in this avulsion cycle (Fig. 5B). This example highlights the two distinct regions of scour observed during the experiment, which were driven by floods and avulsions. In the next sections, we quantify the flood- and avulsion-induced erosional surfaces that occurred during the experiment and compare with the theory.

\section{Flood-Induced Erosional Surfaces}

Figure 5C shows an example of flood-induced scours isolated from phase 1 of the experiment, before any avulsions occurred. Transient channel incision in the backwater reach is evident by the comparison of the bed profiles at the beginning and end of the high-flow event (blue and red profiles). The subsequent low-flow event resulted in deposition through the backwater reach (yellow profile). The flood-induced scours were evaluated as the difference between the bed profiles at the beginning and at the end of the high-flow event (Fig. 5C), and a compilation from all 14 flood events during phase 1 of the experiment were used for our analysis (Fig. 6A). Results indicate that the flood-induced scours were maximum near the shoreline $\left(0.41 \pm 0.04 \mathrm{~m}\right.$, i.e., $0.14 \pm 0.02 L_{b}$, upstream of shoreline $)$ and decayed with upstream distance from the shoreline, consistent with theoretical expectations (Fig. 1A). The mean and standard error of the observed maximum scour depth, $h_{\text {scour }}$, was $3 \pm 0.3 \mathrm{~mm}$, and the dimensionless maximum scour depth was $h_{\text {scour }} / h_{c}=0.31 \pm 0.03$ (Fig. $6 \mathrm{~A})$. The uncertainty in the estimates of maximum scour depths represents the temporal variability across different flood events in phase 1 of our experiment. We note that these values were computed on the channelwidth-averaged bed profiles (see Methods), and the uncertainties in the average erosional signal can be less than the grain size used in our experiment due to spatial averaging. The flood-induced scour lengths extended $2.1 \pm 0.14 \mathrm{~m}$ from the location of maximum flood-induced scour, yielding a dimensionless scour length of $l_{\text {scour }} / L_{b}=0.72 \pm 0.05$ (Fig. 6A).

To compare with theory, we found that the mean and standard error of the temporally averaged normal-flow depths for low and high flows were $9.5 \pm 0.2 \mathrm{~mm}$ and $13 \pm 0.3 \mathrm{~mm}$, respectively, which yield theoretical estimates of maximum flood-induced scours (Equation 1) of $h_{\text {scour }}=3.5 \pm$ $0.5 \mathrm{~mm}$, or $h_{\text {scour }} / h_{c}=0.35 \pm 0.05$. Thus, theory matches the experimental observations within error (Fig. 6A). Our predictions of $h_{\text {scour }}$ based on differencing the high-flow and low-flow normal depths are also in agreement with simulations of Chatanantavet and Lamb (2014). Our analysis of those results shows maximum observed $h_{\text {scour }} / h_{c}=0.72$ and predicted $h_{\text {scour }} / h_{c}=0.9 \pm 0.2$.

We also predicted $l_{\text {scour }}$ for flood-induced scours using Equation 5, where, for our experiment, $t_{\text {scour }}=900 \mathrm{~s}$ and the dimensional diffusivity, $\kappa$ $=q_{s} / S$ with $S=3.3 \times 10^{-3}$ and $q_{s}=1.1 \times 10^{-5} \mathrm{~m}^{2} / \mathrm{s}$ (volumetric sediment feed rate per unit width for the high flow). This yielded theoretical estimates for the dimensional and dimensionless length scale of floodinduced scours of $l_{\text {scour }}=1.73 \mathrm{~m}$ and $l_{\text {scour }} / L_{b}=0.61$, respectively (Fig. $6 \mathrm{~B})$. The theoretical flood-induced scour length is within $15 \%$ of the experimental observation. Also included on Figure $6 \mathrm{~B}$ are the model predictions and observed scour lengths from the simulations of Chatanantavet and Lamb (2014). Our simple model predictions of floodinduced scour lengths are within $50 \%$ of the lengths observed in their work.

\section{Avulsion-Induced Erosional Surfaces}

The avulsion-induced scour depths from phase 3 of the experiment were maximum at $0.46 \pm 0.1 L_{b}$ upstream of the shoreline, which coincided with the location of the avulsion sites $\left(0.48 \pm 0.1 L_{b}\right.$ upstream of shoreline (Ganti et al. 2016b)). The experimental avulsion-induced scour depths decayed with upstream distance from the avulsion site, consistent with theoretical expectations (Fig. 1B). The mean and standard error of the observed maximum dimensionless avulsion-induced scour depth was $h_{\text {scour }} / h_{c}=0.3 \pm 0.1$ (Fig. 6A). The scour lengths extended $4.35 \pm 0.6 \mathrm{~m}$ upstream of the location of maximum scour depths yielding a dimensionless avulsion-induced scour length of $l_{\text {scour }} / L_{b}=1.49 \pm 0.2$ (Fig. 6A).

We estimated the theoretical $h_{\text {scour }}$ resulting from avulsions using Equation 3. The mean and standard error of the dimensionless avulsion threshold was $h^{*}=0.35 \pm 0.04$ (Ganti et al. 2016b), which matched the maximum dimensionless scour depths observed in the experiment within error (Fig. 6A). We estimated the theoretical avulsion-induced scour length, $l_{\text {scour }} / L_{b}$, using Equation 6 with $t_{\text {scour }}=t_{A}$, and evaluated the dimensionless avulsion timescale, $t_{A}^{*}$, using Equation 16a with $h^{*}=0.35 \pm$ $0.04, L_{A}^{*}=0.48 \pm 0.1$, and $B^{*}=10.5$ (Ganti et al. 2016b). The mean and standard error (computed by formally propagating the uncertainties in $h^{*}$ and $L_{A}^{*}$ through Equations 16a and 6) of the predicted dimensionless avulsion-induced scour length was $l_{\text {scour }} / L_{b}=1.94 \pm 0.13$. This theoretical dimensionless avulsion-induced scour length is within $30 \%$ of the experimental observation (Fig. 6B).

\section{Preserved Shoreline Trajectories}

Shoreline trajectories describe the cross-sectional path of the shoreline as it migrates in a direction parallel to the depositional dip, and they provide a complementary record of scour surfaces. Figure 7B shows experimental synthetic stratigraphy in the depositional-dip direction where the shoreline positions are indicated as gray markers. Measured from the change in confinement in the experimental facility, the experimental shoreline trajectories first record the initial phase of delta-topset aggradation followed by pronounced delta-front progradation over a downstream distance of $\sim 0.3 L_{b}$ (Fig. 7B, C). As the delta grew larger, there are two locations in the stratigraphy that show evidence of a vertical drop in the shoreline trajectories that are interspersed within an overall trend of delta-front progradation (Fig. 7C). Results indicate that the erosional scours that caused a vertical drop in the shoreline trajectories occurred during the third phase of the experimental deltaic evolution, i.e., $t>66 \mathrm{hr}$ (Fig. 7B). The scale of the vertical drop in the 

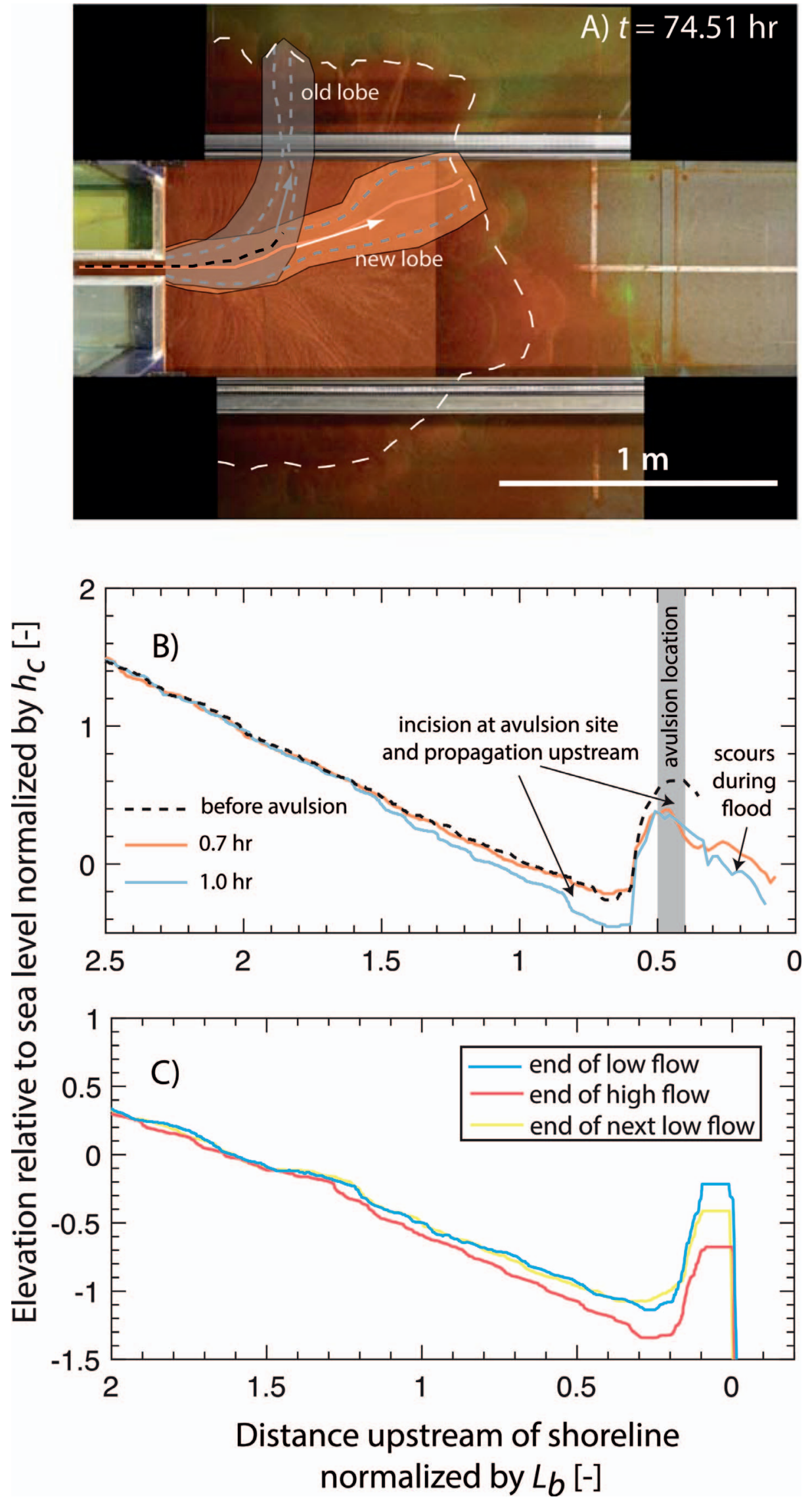

FIg. 5.-A) Example lobe-switching event observed in the experiment for an avulsion that occurred at $t=74.5 \mathrm{hr}$. The timescale of the avulsion cycle starting at $t=74.5 \mathrm{hr}$ was $t_{A}=3.2$ hr. Overhead image of the experimental delta at $t$ $=74.51 \mathrm{hr}$ where the old and new delta lobes are indicated by the shaded gray and orange regions, respectively. The white dashed line indicates the shoreline, and dashed gray lines indicate the old and new channel margins. The extent of the width-averaged long profiles shown in Part B are highlighted on the image. B) Plot of the dimensionless width-averaged channel bed elevation as a function of the distance upstream of the shoreline normalized by the backwater length $\left(L_{b}\right.$ $=2.9 \mathrm{~m}$ ). The dashed black line shows the bed elevation upstream of the avulsion site immediately before an avulsion that occurred at $t=74.5$ $\mathrm{hr}$. The orange profile shows the bed profile $0.7 \mathrm{hr}$ after the avulsion occurred, and incision at the avulsion location is evident. The cyan profile shows the bed $1 \mathrm{hr}$ after the avulsion where erosional scours near the shoreline resulting from the flood event and the upstream propagation of the avulsion-induced scours are evident. The gray shaded area denotes the uncertainty in measurement of the avulsion location, which was equal to the channel width (Ganti et al. 2016a). C) Plot showing the dimensionless width-averaged channel-bed elevation as a function of the distance upstream of the shoreline normalized by $L_{b}$. The blue, red, and yellow profiles show the channel bed elevation at $t=4.7 \mathrm{hr}, 5 \mathrm{hr}$, and $5.7 \mathrm{hr}$, respectively. Channel-bed incision driven by the high-flow event from $t=4.7$ to $5 \mathrm{hr}$ is evident from the comparison of the blue and red profiles. 

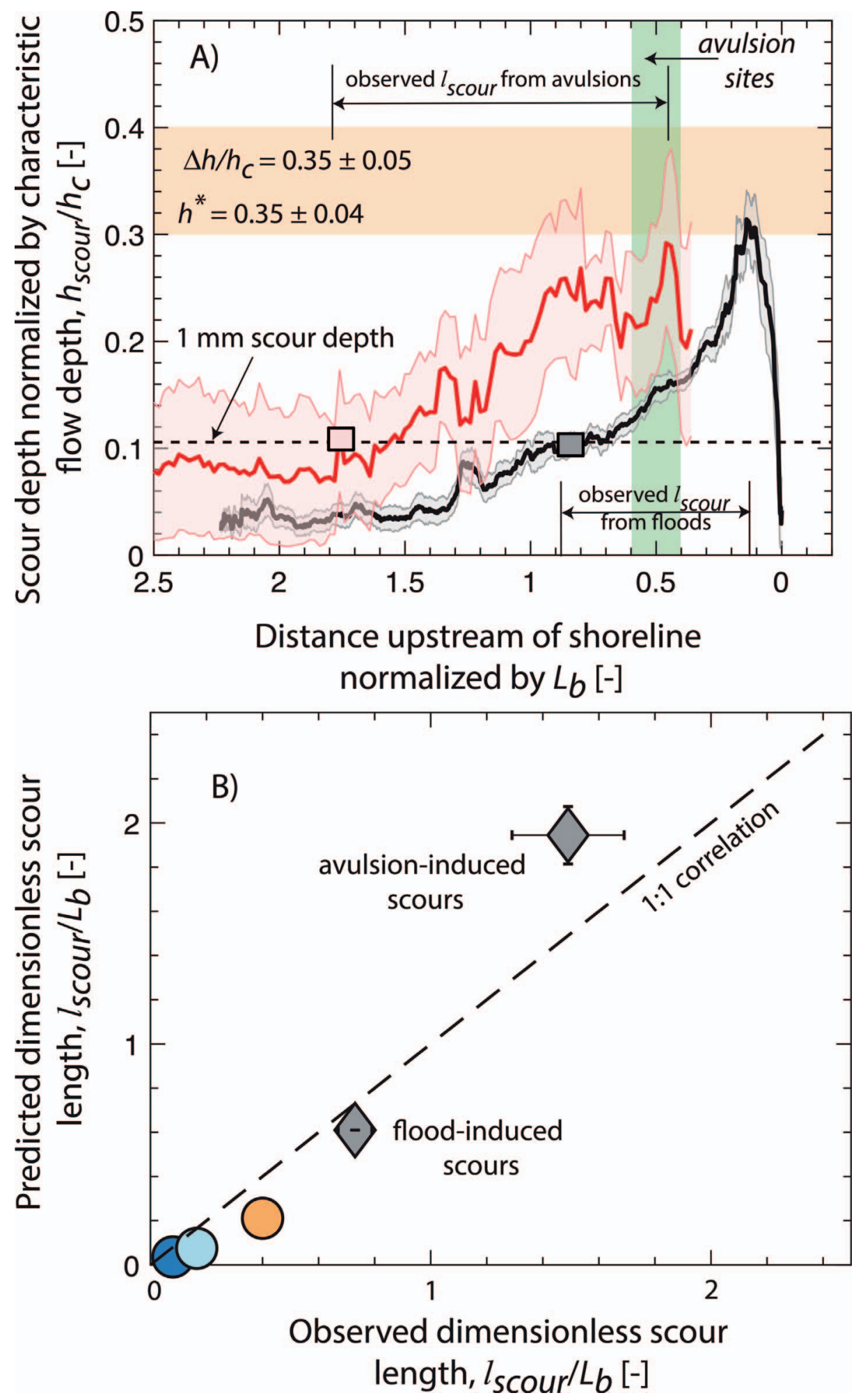

FIG. 6.-Summary of observed erosional scours on the experimental backwater-mediated delta. A) Plot showing the measured floodinduced (solid black line) and avulsion-induced (solid red line) scour depths normalized by characteristic flow depth $\left(h_{c}=9.5 \mathrm{~mm}\right)$ as a function of distance upstream of the shoreline normalized by the backwater length $\left(L_{b}=2.9 \mathrm{~m}\right)$. The solid line denotes the mean, and the shaded area around the solid line denotes the standard error of the measured erosional scour depths. Flood-induced scours were averaged over 14 flood cycles from $t=0$ to $13.9 \mathrm{hr}$, before avulsions occurred on the experimental delta (phase 1 of the experiment), and avulsion-induced scours were averaged over six backwater-mediated avulsion cycles (phase 3 of the experiments). The orange shaded region represents the theoretical expectation of maximum flood- and avulsion-induced scours from Equations 1 and 3, respectively. The green shaded area denotes the avulsion sites along with the uncertainty in measurement of the avulsion locations, which was equal to the channel width (Ganti et al. 2016a). The dashed black line denotes a scour depth of $1 \mathrm{~mm}$, and the square markers denote the $e$-folding distance of erosional scours. B) Comparison of the predicted and observed dimensionless scour length for floodand avulsion-induced scours (see text for details of their computations). The error bar for the observed dimensionless flood-induced scour length was less than the marker size. The colored circles correspond to times since the onset of flooding of $3 \mathrm{~min}$ (blue), $13 \mathrm{~min}$ (cyan), $103 \mathrm{~min}$ (orange) from the flume-calibrated simulations of Chatanantavet and Lamb (2014) (see their Fig. 4D). We calculated the diffusivity, $\kappa$, for their high-flow event using the same equilibrium bed slope $\left(S=1.5 \times 10^{-3}\right)$ and the volumetric unit sediment flux per unit width in the normal flow reach $\left(q_{s}=2 \times 10^{-5} \mathrm{~m}^{2} / \mathrm{s}\right)$ that they used in the simulations. Note that their calculations of sediment flux incorporated a form-drag correction, computed using the method of Wright and Parker (2004), which was not reported in their paper. shoreline trajectories is $\sim 0.3 h_{c}$, consistent with flood- and avulsion-induced scours, and the length scale over which the shoreline trajectories migrate seaward is $\sim 0.1$ to $0.15 L_{b}$ (Fig. $7 \mathrm{C}$ ). Thus, our results indicate that fluctuations proportional to the maximum autogenic scour depths (which are on the scale of a few channel depths; see Equations 1 and 3, and Trower et al. 2018) are expected in the shoreline trajectories preserved in the stratigraphic record of backwater-mediated deltas even under steady relative sea level.

\section{ANALYSIS: APPLICATION TO NATURAL DELTAS}

Our experimental results confirm the theoretical expectations that floodinduced and avulsion-induced scours start near the shoreline and the avulsion site, respectively, and propagate upstream (Fig. 6). Comparison of the predicted and observed dimensionless scour lengths from floods and avulsions (Fig. 6B) indicate good agreement between theory and 

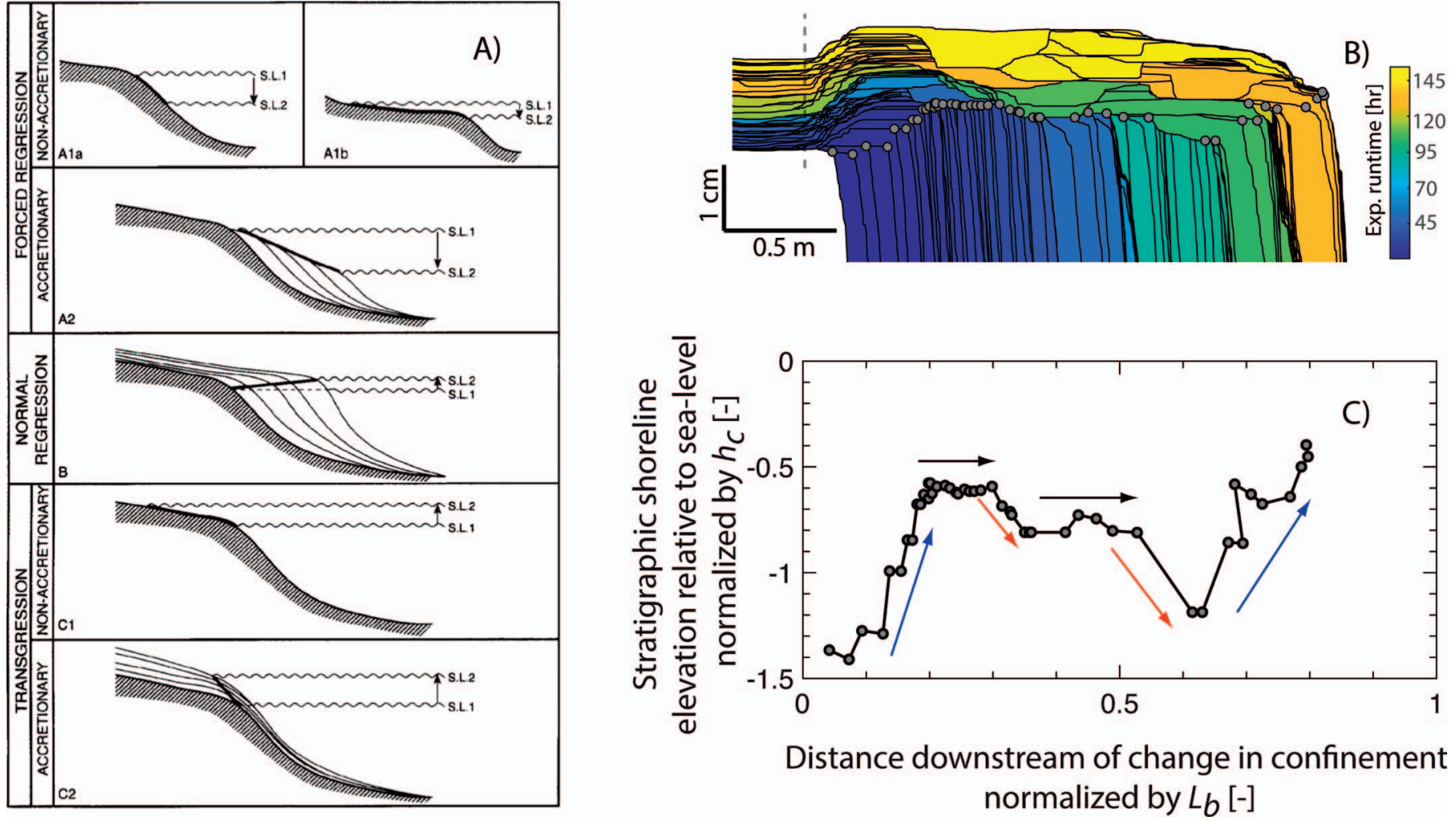

FIG. 7.-Classical interpretation of shoreline trajectories and preserved shoreline trajectories in experimental stratigraphy. A) Various classes of shoreline trajectories (heavy solid line) and the interpretation of their origin in terms of changes in relative sea level (the black arrows indicate the direction of relative sea-level change). In accretionary settings, the sediment accumulation at the shoreline plays an important role in defining shoreline trajectory. In contrast, in non-accretionary settings, the shoreline translates along pre-existing topography. Figure is reproduced from Helland-Hansen and Martinsen (1996). B) Experimental synthetic stratigraphy built from the time series of topographic measurements along the flume centerline, i.e., in the depositional-dip direction (see Fig. 4A for transect location). The black lines indicate the bounding surfaces, and the color indicates the time of deposition of each sedimentary package. The gray dashed line indicates the location of change in confinement in the experimental facility. The gray markers indicate the preserved delta topset-foreset rollover in experimental stratigraphy. C) Plot showing the stratigraphic shoreline elevation relative to the mean sea level normalized by the characteristic flow depth $\left(h_{c}=9.5 \mathrm{~mm}\right)$ as a function of the distance downstream of the change in confinement normalized by the backwater length $\left(L_{b}\right.$ $=2.9 \mathrm{~m}$ ). Preserved shoreline trajectories can be classically interpreted as multiple cycles of aggradation (blue arrow), progradation (black arrow), and forced regression (red arrow).

experimental observations, thus validating the proposed scaling relationships and the mass-balance framework. Using our theoretical framework, we now explore the length scales over which autogenic erosional scours propagate on backwater-mediated deltas for parameter ranges relevant to field cases.

\section{Flood-Induced Scour Lengths}

Our theoretical framework indicates that the dimensionless length scale over which flood-induced scours propagate is a function of the following quantities (Equation 10):

$$
\frac{l_{\text {scour }}}{L_{b}}=f\left(S, h_{c}, D_{50}, t_{\text {scour }}\right)
$$

Model predictions indicate that the flood-induced scour lengths $\left(l_{\text {scour }}\right)$ should increase with the characteristic flow depth $\left(h_{c}{ }^{5 / 4}\right)$ and channel-bed slope $\left(S^{3 / 4}\right)$, and decrease with median grain size $\left(D_{50}{ }^{-1 / 2}\right)$. Given the weaker dependence on median grain size, we explored the parameter space by systematically varying $h_{c}$ and $S$ over the observed range of values for natural backwater-mediated deltas (Table 1), i.e., $h_{c} \in[2,25] \mathrm{m}$ and $S \in\left[10^{-5}, 10^{-3}\right]$. Figure $8 \mathrm{~A}$ and B show the dimensionless flood-induced scour length for a flood duration of one week and one month, respectively.

Our model predicts that the upstream extent of the flood-induced scours increases with longer flood durations, deeper flow depths, and steeper bed slopes, and decreases with coarser grain sizes (Fig. 8). Longer duration flood events allow for the propagation of the flood-induced scours farther upstream such that the entire alluvial reach tends to equilibrium, normalflow conditions with the given flood event, consistent with previous experimental and modeling observations (Chatanantavet and Lamb 2014). The celerity of the erosional-wave propagation in a linear diffusive system is proportional to the square root of diffusivity (Equation 5 , if $q_{s} / S$ is not a function of $x$ ), which increases with channel-bed slope (because volumetric sediment flux increases faster than linearly with $S$; Equation 8) and characteristic flow depth, and decreases with median grain size.

On natural river deltas, flood durations typically range from days to months. Our results indicate that flood-induced scours on steep river deltas may propagate the entire backwater length for a flood duration on the order of a month (Fig. 8). In contrast, the flood-induced scours for low-gradient rivers like the Mississippi, the Paraná, and the Danube, which have backwater lengths on the order of $100 \mathrm{~km}$, are likely to propagate $0.1 L_{b}$ to $0.5 L_{b}$ upstream of the shoreline for flood events of typical duration (Fig. 8). Our predictions are consistent with field observations and previous modeling of localized scour within the lowermost $\sim 100 \mathrm{~km}$ of the Mississippi $\left(\sim 0.21 L_{b}\right)$ (Nittrouer et al. 2011; Lamb et al. 2012) and theoretical estimates of characteristic bed-adjustment timescales $\left(t_{\text {adj }}\right.$; Equation 7) of 50 to 80 years for low-gradient rivers (Chatanantavet and Lamb 2014). Trower et al. (2018) documented erosional scours in the Upper Cretaceous Castlegate Sandstone that extend $\sim 0.5$ to $1 L_{b}$ upstream 


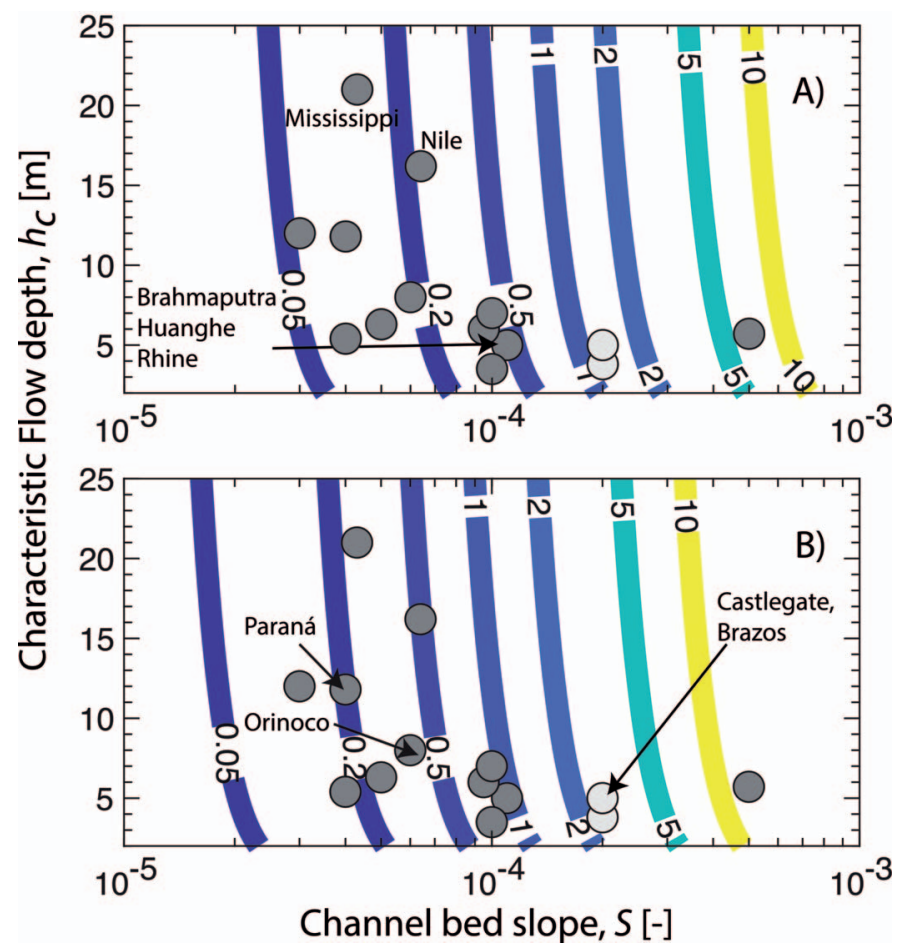

FIG. 8.-Contour plot showing the dimensionless flood-induced scour lengths as a function of the characteristic flow depth and channel-bed slope for a flood duration of A) one week and B) one month (equation 10 with $h_{n}=3 h_{c}$ ). The thickness of the contour lines encompasses a median grain size of 0.3 to $0.5 \mathrm{~mm}$, which covers the majority of the measured $D_{50}$ values on natural backwater-mediated deltas (Table 1). The dark gray markers correspond to the extant delta systems reported in Table 1, and the light gray markers denote ancient delta systems of the Upper Castlegate Sandstone and the paleo-Brazos River.

of the paleoshoreline, and attributed these scours to floods. Our theory suggests that flood durations on the scale of a week can result in the observed erosional scour lengths of the Castlegate Sandstone (Fig. 8).

\section{Avulsion-Induced Scour Lengths}

Our theoretical framework suggests that the dimensionless avulsioninduced scour length is a function of the following dimensionless parameters (Equation 15):

$$
\frac{l_{\text {scour }}}{L_{b}}=f\left(B^{*}, \sigma^{*}, h^{*}, L_{A}^{*}\right)
$$

Given the model constraints in Equations 17 and 19, we solved Equation 15 for the dimensionless avulsion timescale, $t_{A}^{*}$, with $n=1$ for a range of values of the dimensionless variables in Equation 21: $\sigma^{*} \in[-1,2]$, $h^{*} \in[0.1,10], L_{A}^{*} \in[0.1,10]$, and $B^{*} \in\left[10^{0}, 10^{3}\right]$, which encompass the estimated parameters for the field cases (Table 1). We then estimated the dimensionless avulsion-induced scour length using Equation 6 with $t_{\text {scour }}=$ $t_{A}$. To explore parameter space, we systematically varied $\sigma^{*}$ and one of the variables of $B^{*}, L_{A}^{*}$ or $h^{*}$, holding the other two dimensionless variables constant, which were set to the mean of the field data compilation reported in Table 1.

Results show that the dimensionless avulsion-induced scour length decreases with the bed-adjustment timescale (Equation 6). The bedadjustment timescale is in turn inversely proportional to the unit sediment flux needed to aggrade the riverbed by $h_{\text {fil }}$ over an avulsion cycle (Equation 7; Fig. 2). Relative sea-level rise aids net aggradation on the
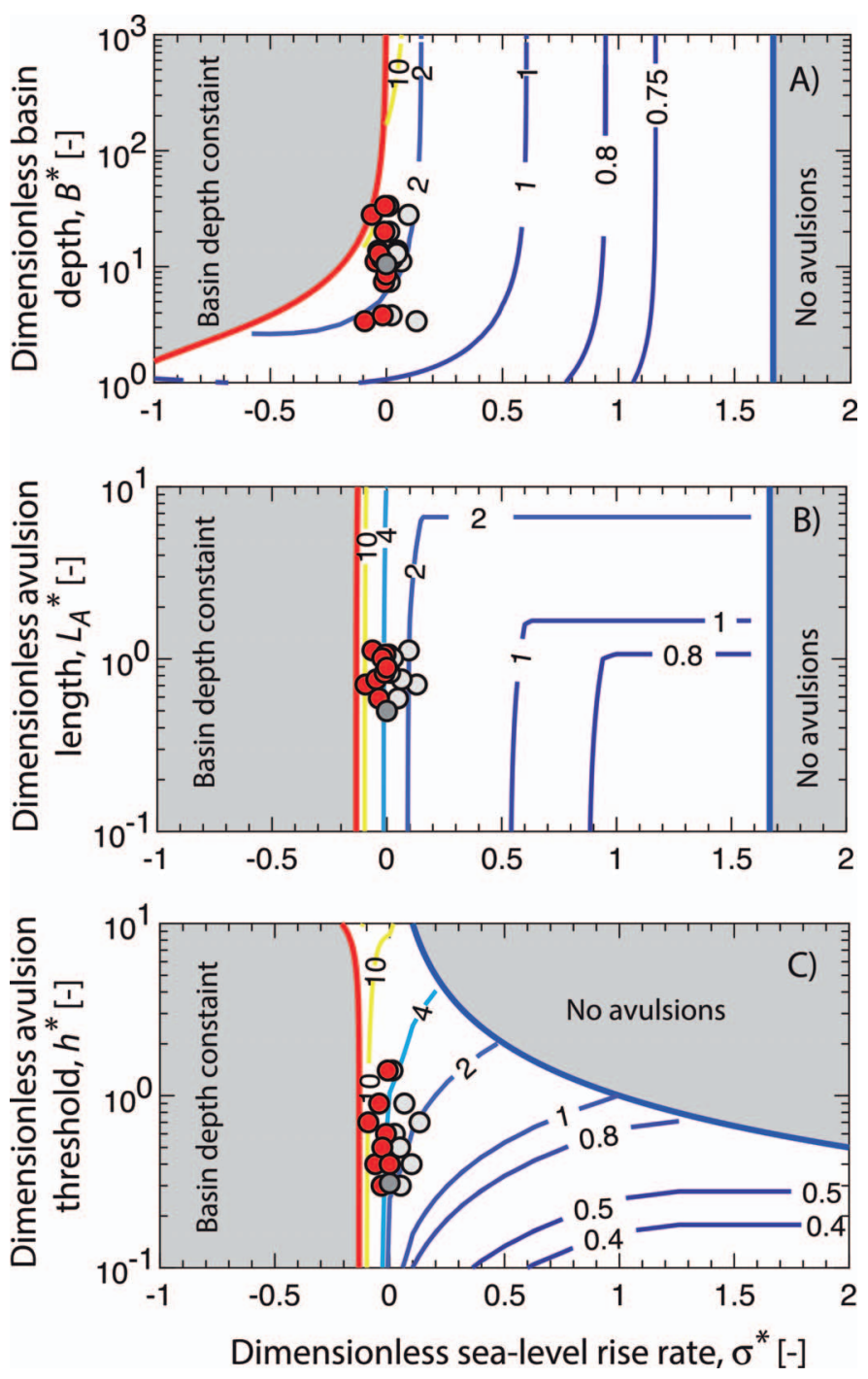

FIG. 9.-Functional dependence of the dimensionless avulsion-induced scour length on the dimensionless parameters shown in Equation 21. Contours of dimensionless avulsion-induced scour length as a function of $\mathbf{A}$ ) dimensionless basin depth, $B^{*}$ (with $L_{A}^{*}=0.9$ and $h^{*}=0.6$ ), B) dimensionless avulsion length, $L_{A}^{*}$ (with $B^{*}=15$ and $h^{*}=0.6$ ), C) dimensionless avulsion threshold, $h^{*}$ (with $L_{A}^{*}=0.9$ and $B^{*}$ $=15$ ) and the dimensionless sea-level rise rate, $\sigma^{*}$. The gray shaded areas in all these panels indicate the model parameter constraints given in Equations 17 and 19. The experimental data point is shown as the dark gray marker, and the field examples for the estimated dimensionless relative sea-level rise and fall are shown as light gray and red markers, respectively (Table 1).

delta plain, and therefore the amount of progradation-induced aggradation needed to trigger an avulsion is less than that expected for the case of steady relative sea level (Fig. 2B). Thus, the avulsion-induced scour lengths are expected to be lower during relative sea-level rise (Fig. 9). In contrast, during relative sea-level fall, the basin depth decreases; however, the amount of progradation needed to aggrade the riverbed by $h_{\text {fil }}$ is higher (Fig. 2C), and consequently the total amount of sediment volume needed to balance mass during an avulsion cycle is higher, thus increasing the dimensionless avulsion-induced scour length (Fig. 9). Similarly, for a given relative sea-level rise (or fall) rate, our model predicts an increase in the dimensionless avulsion-induced scour length with an increase in basin depth (Fig. 9A), avulsion length (Fig. 9B), and critical in-channel sedimentation necessary to trigger avulsions (Fig. 9C) because the volume 


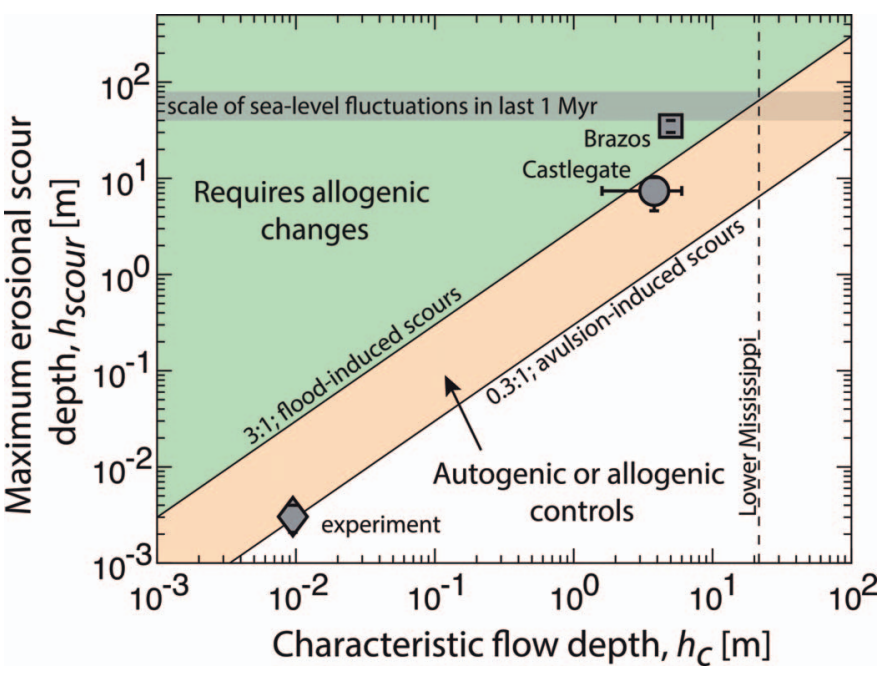

FIG. 10.- Phase space for delineating autogenic and allogenic controls on erosional boundaries in fluvio-deltaic stratigraphy. Plot of the maximum erosional scour depth $\left(h_{\text {scour }}\right)$ as a function of the characteristic flow depth $\left(h_{c}\right)$. The orange shaded area $\left(0.3 h_{c} \leqslant h_{\text {scour }} \leqslant 3 h_{c}\right)$ delineates the region of erosional scours expected from autogenic dynamics of backwater-mediated deltas. The green shaded area represents the region where erosional scour depths are greater than those predicted from autogenic dynamics $\left(h_{\text {scour }}>3 h_{c}\right)$. Maximum erosional scour depths and reconstructed characteristic flow depths from the Upper Cretaceous Castlegate Sandstone (gray circle) and Quaternary paleo-Brazos River deposits (gray square) reported in Trower et al. (2018) are plotted along with the experimental data point (gray diamond; flood-induced and avulsion-induced scours plot on top of each other). The dashed line indicates the characteristic flow depth of the lower Mississippi River, and the shaded gray area denotes the scale of reconstructed sealevel fluctuations over last 1 Myr (Bintanja et al. 2005).

of sediment needed to prograde the delta lobe and aggrade the riverbed by $h_{\text {fill }}$ during an avulsion cycle increases, thus decreasing the bed-adjustment timescale (Equation 7).

For all values of $B^{*}, L_{A}{ }^{*}$, and $h^{*}$ relevant to field cases, the dimensionless avulsion-induced scour length ranged from 2 to 5 for steady relative sea level (Fig. 9). In comparison, the predicted dimensionless avulsion-induced scour length for $\sigma^{*}>0$ and $\sigma^{*}<0$ ranged from 2 to 4 and 4 to 10 , respectively (Fig. 8). These results indicate that autogenic avulsion-induced scours can be spatially more extensive and propagate significantly farther than $L_{b}$ during relative sea-level fall (Fig. 9). We note these predictions of long erosional scours do not correspond to allogenic scours resulting from sea-level fall, but instead correspond to erosional scours that occur on net aggradational deltas under modest rates of relative sea-level fall (Fig. 2C). Our model, however, cannot predict scours due to forced river incision (e.g., due to sea-level fall or reduced sediment supply relative to sediment transport capacity) because it applies only to net-aggrading deltas undergoing repeated avulsions (Fig. 2).

Taken together, our results indicate that flood-induced scours start at the shoreline and extend by an upstream distance that scales with $L_{b}$, and avulsion-induced scours start at the avulsion site, which is a characteristic distance upstream of the shoreline that scales with $L_{b}$. Thus, flood- and avulsion-induced scours can amalgamate to result in a spatially extensive erosional surface that spans a multiple of a few backwater lengths even under constant allogenic conditions (Fig. 6A).

\section{DISCUSSION}

Our results suggest that floods and avulsions can result in broad erosional surfaces in fluvio-deltaic stratigraphy, even under steady relative sea level (Figs. 6, 9). Synthetic stratigraphic sections show stacked and amalgamated channel bodies bounded by erosional surfaces and apparent "incised" valleys, which are often classically associated with changes in relative sea level. At or upstream of the avulsion sites (Fig. 4B, C), our experiments show that deep scours that appear similar to incised valleys in stratigraphy can be created by avulsion-induced scours, which are later filled with stacked channel deposits, indicating that the incised valleys preserved in stratigraphy likely represent an amalgamation of timeintegrated geomorphic surfaces (Strong and Paola 2008). Downstream of the avulsion sites, superimposed multi-story channel bodies can result from shifts in depocenter due to avulsions and reoccupation of previously channelized locations both in the depositional-dip direction (Fig. 7B) and in strike-oriented sections (Figs. 4D, E).

Backwater-induced scours can also result in non-monotonic trends of shoreline trajectories preserved in fluvio-deltaic stratigraphy, which are often interpreted in terms of base-level changes (e.g., Helland-Hansen and Martinsen 1996). Autogenic scours result in shoreline trajectories that drop vertically in the seaward direction even under steady allogenic conditions, and appear similar to those resulting from forced regression in accretionary settings due to relative sea-level fall (Fig. 7). The amount of vertical drop in shoreline positions resulting from flood-induced scours is equal to a few times the channel depth (Figs. 7, 10); this indicates that shoreline trajectories preserved in the stratigraphy of low-gradient, large rivers can show apparent cyclicity with a vertical scale of 10 to $100 \mathrm{~m}$ even under steady allogenic conditions. Further, shoreline trajectories recorded in backwater-mediated deltas evolving under relative sea-level rise have the potential to be misconstrued to represent multiple cycles of relative sealevel change owing to localized scour near the shoreline from floods, which result in a vertical drop in shoreline trajectories. Flood-induced scours may also accentuate the vertical drop in shoreline trajectories under modest rates of relative sea-level fall, which may result in the overestimation of rates of relative sea-level fall.

Given the complications that arise in interpreting erosional surfaces in fluvio-deltaic stratigraphy, we need a means to identify erosional surfaces generated by autogenic processes to separate them from allogenic signals. Here we focus on the lateral extent, streamwise extent, and depth of autogenic scour surfaces formed by backwater-mediated floods and avulsions.

Allogenic erosional surfaces from base-level fall are often thought to be much wider than the channel width because of lateral migration of the channel across the channel belt during lowstand. In a similar manner, autogenic erosional surfaces, which may initially have lateral extents that scale with the river width, should also amalgamate into much broader surfaces due to channel lateral migration and avulsions within a channel belt, as well as major lobe-switching avulsions that can juxtapose generations of channel belts (Best and Ashworth 1997). Channel belts are often narrower in backwater zones due to reduced lateral migration rates as compared to farther upstream (Lamb et al. 2012; Blum et al. 2013; Fernandes et al. 2016; Durkin et al. 2017), which should affect the lateral extent of flood-induced erosional surfaces in the backwater zone. In contrast, avulsion-induced scours, which propagate upstream of the backwater zone (Figs. 6,9), are likely to be laterally more extensive if the channel is in an unconfined valley. Given steady base level and climate, autogenic scour depths are expected to be similar in consecutive floods and avulsions, making amalgamation across the channel-belt likely. Consistent with these ideas, our experiment shows scour surfaces with lateral extents of 30 to $40 \mathrm{~cm}$ - compared to channel widths of 10 to $30 \mathrm{~cm}$ - resulting from amalgamation of multiple flood scours within a single avulsion cycle (Fig. 4). Amalgamated scour surfaces generated over multiple avulsion cycles are even wider (Fig. 4). Thus, the lateral extent of autogenic, amalgamated erosional surfaces is likely to be similar to allogenic unconformities.

While other autogenic erosional scour mechanisms such as river-bend migration and river confluence likely result in erosional scours that are 
localized in the streamwise direction, backwater-related erosional scours have the potential to extend long distances upstream. For example, Best and Ashworth (1997) reported erosional scour lengths of 2 to $5 \mathrm{~km}$ resulting from the confluence of the Ganges and the Brahmaputra. Our theory indicates that floods of typical duration on the Brahmaputra can result in a maximum erosional scour depth of $\sim 21 \mathrm{~m}\left(h_{c}=7 \mathrm{~m}\right.$ for Brahmaputra; Table 1, Fig. 8) near the river mouth, and these erosional scours can extend several tens of kilometers upstream $\left(L_{b}=70 \mathrm{~km}\right.$ for Brahmaputra; Table 1, Fig. 8). Scour lengths due to floods and avulsions are expected to scale with the backwater length, and may extend from the shoreline to well upstream of the avulsion node (Figs. 6, 8, 9). Given that backwater lengths of large, lowland rivers can be hundreds of kilometers (e.g., $L_{b} \approx 480 \mathrm{~km}$ for the Mississippi River; Table 1), the length of autogenic scours can be regional in extent (Fig. 9), and similar in scale to surfaces often interpreted to result from base-level fall (e.g., Trower et al. 2018).

In contrast to lateral and streamwise extents of scours, scour depth may be more useful in identifying autogenic erosional surfaces in the stratigraphic record. Autogenic scour depths from floods and avulsions in the backwater zone scale with channel depth, similar to channel-bend and confluence scour (Best and Ashworth 1997; Eilertsen and Hansen 2008). Maximum dimensionless scour depths from avulsions scale with the dimensionless avulsion threshold, which is proportional to the characteristic flow depth $\left(h_{\text {scour }} \approx h_{c}\right.$; Table 1$)$ (Mohrig et al. 2000; Jerolmack and Mohrig 2007; Ganti et al. 2014a, 2016b). The maximum scour depths from floods scale with the difference between normal-flow depths of typical low-flow and high-flow events, and modern compilations of discharge data suggest $h_{\text {scour }} \approx 2 h_{c}$ to $4 h_{c}$ (Gibling 2006; Ganti et al. 2014a; Trower et al. 2018). While our experimental erosional scour depths show two prominent peaks near the shoreline and the avulsion sites (Fig. 6A), the erosional scour depths observed in the field are likely to decay monotonically with distance upstream of the shoreline (Trower et al. 2018) because the maximum flood-induced scour depths $\left(h_{\text {scour }} \approx 3 h_{c}\right)$ are expected to be significantly larger than the avulsion-induced scour depths $\left(h_{\text {scour }} \approx h_{c}\right)$.

The maximum flood-induced scour depths given by Equation 1 may not always be reached during a single flood event, due to flood-duration limitations. For example, in our experiment (Fig. 6A), the flood-induced scours reached the theoretical maximum of $\Delta h$ at the river mouth for $t_{\text {scour }}$ $t_{a d j}=0.37$. In contrast, the maximum flood-induced scour depths at the river mouth in the flume-calibrated numerical model of Chatanantavet and Lamb (2014) were $20 \%, 33 \%$, and $55 \%$ of the maximum $h_{\text {scour }}$ at equilibrium high-flow conditions for $t_{\text {scour }} / t_{\text {adj }}=0.0013,0.0057$, and 0.0445 , respectively. These results indicate that the theoretical maximum of $h_{\text {scour }} \approx \Delta h$ is realized only when the flood duration is long enough such that $t_{\text {scour }} / t_{\text {adj }}$ is greater than order of $10^{-1}$; however, flood-induced scours can reach a significant fraction (20-50\%) of $\Delta h$ for $t_{\text {scour }} / t_{\text {adj }}$ of $10^{-3}$ to $10^{-2}$. Moreover, multiple large flood events occurring closely in time could create deeper total scour depths, akin to a cumulative $t_{\text {scour }} / t_{\text {adj }}>0.1$. For large, low-gradient rivers like the Mississippi, the Paraná, and the Danube, $t_{\text {scour }} / t_{\text {adj }}>0.1$ would correspond to flood durations greater than a few years, suggesting that flood-induced scours are likely some fraction of $\Delta h$ for a single flood event. In contrast, for steeper river systems like the Rhine, the Huanghe, and the Brahmaputra, $t_{s c o u r} / t_{a d j}>0.1$ corresponds to flood durations of a few months, indicating that flood-induced scour depths may reach the maximum.

Plotting the maximum erosional scour depths as a function of characteristic flow depth provides a framework for distinguishing autogenic versus allogenic controls on the erosional boundaries in fluvio-deltaic stratigraphy (Fig. 10) (Trower et al. 2018). For observed $h_{\text {scour }}$ that spans $0.3 h_{c}$ (observed minimum $h_{\text {fill }}$ ) to $3 h_{c}$ (observed maximum normal-flow depth variability in modern systems), it is difficult to isolate allogenic from autogenic erosional surfaces, owing to the scale overlap with scour from floods and avulsions. In contrast, erosional scour depths well in excess of the predicted maximum flood-induced scours, i.e., $h_{\text {scour }}>3 h_{c}$, are most likely to be allogenic in origin.

To illustrate the utility of this framework, we analyzed the maximum erosional scour depths measured in the lowest $\sim 10 \mathrm{~km}$ fluvial section of the Upper Cretaceous Castlegate Sandstone (Trower et al. 2018) and the measured incised valley depths in the Quaternary deposits of the paleoBrazos River in Texas (Abdulah et al. 2004; Blum and Aslan 2006) (Fig. $10)$. The measured $h_{\text {scour }}$ values from the Castlegate Sandstone overlap with predictions of autogenic scours resulting from floods and avulsions (Fig. 10) consistent with the work of Trower et al. (2018) and suggest that the role of base-level fall in creating the erosional surfaces is ambiguous. However, the estimated scale of incised valleys in the paleo-Brazos River exceed the maximum $h_{\text {scour }}$ from autogenic dynamics alone (Trower et al. 2018). This observation supports the interpretation that incised valleys in the paleo-Brazos system were a result of sea-level fall driven by Pleistocene glaciation (Abdulah et al. 2004; Blum and Aslan 2006; Rohling et al. 2009).

Decoupling autogenic and allogenic controls on erosional surfaces may be especially problematic in large, low-gradient river systems. For example, $h_{c} \approx 21 \mathrm{~m}$ and $L_{b} \approx 480 \mathrm{~km}$ for the Mississippi River (Table 1 ), which indicates that the expected autogenic erosional scour depths for such a system can rival the scale of the largest Quaternary sea-level cycles (Fig. 10). Our results support the notion that smaller sedimentary systems with limited spatiotemporal scales of autogenic dynamics may record allogenic changes with higher fidelity (Castelltort and Van Den Driessche 2003; Jerolmack and Paola 2010; Ganti et al. 2014b; Li et al. 2016; Foreman and Straub 2017; Yu et al. 2017).

\section{CONCLUSIONS}

Based on a new theoretical analysis combined with experimental and field data, we find that:

1. Autogenic erosional surfaces can form due to floods and avulsions on river deltas even under constant relative sea level, and both of these processes are controlled by backwater hydrodynamics.

2. Maximum autogenic scour depth from floods and avulsions scale with a multiple of the characteristic flow depth $\left(h_{\text {scour }} \sim 0.3\right.$ to $3 h_{c}$ ).

3. Flood- and avulsion-induced scours have maxima near the shoreline and the avulsion site, respectively, and extend upstream from there. Flood-induced scour lengths are longer for larger-duration floods, deeper channels, steeper bed slopes, and finer bed grain sizes. In contrast, avulsion-induced scour lengths are longer for smaller relative sea-level rise rate (or modest fall rates), larger basin depth, and deeper and lower-gradient channels with longer avulsion lengths.

4. Autogenic scours on backwater-influenced deltas can result in a vertical drop in shoreline trajectories in the seaward direction, similar in scale to those resulting from forced regression due to relative sealevel fall.

We combine these new insights to propose a quantitative framework for the expected stratigraphic architecture arising from autogenic dynamics to detangle the relative roles of autogenic and allogenic processes in lowland, backwater-influenced river deltas. Together our results indicate that the lowermost reaches of alluvial rivers ( $\sim 1$ to $5 L_{b}$ upstream of shoreline) are a dynamic zone of persistent channel-bed adjustment on decadal (typical flood recurrence timescales) to millennial (typical avulsion timescales for large, low-gradient rivers) timescales that can result in a rich stratigraphic architecture even in the absence of changes in boundary conditions such as climate, tectonics, and eustasy. 


\section{ACKNOWLEDGMENTS}

We thank Woodward Fischer and Elizabeth Trower for useful discussions. This work was supported by the Caltech Terrestrial Hazard Observation and Reporting program and National Science Foundation grant 1427177 to MPL. VG and MPL acknowledge additional support from the Junior Research Fellowship and the Royal Academy of Engineering Distinguished Visiting Professor Fellowship from the Imperial College London, respectively.

\section{REFERENCES}

Abdulah, K.C., Anderson, J.B., Snow, J.N., And Holdford-Jack, L., 2004, The Late Quaternary Brazos and Colorado deltas, offshore Texas, U.S.A.: their evolution and the factors that controlled their deposition, in Anderson, J.B., and Fillon, R.H., eds., Late Quaternary Stratigraphic Evolution of the Northern Gulf of Mexico Margin: SEPM, Special Publication 79, p. 237-271.

Adams, M.M., and BhatTacharya, J.P., 2005, No change in fluvial style across a sequence boundary, Cretaceous Blackhawk and Castlegate formations of Central Utah, U.S.A Journal of Sedimentary Research, v. 75, p. 1038-1051.

Ainsworth, R.B., Vakarelov, B.K., MacEachern, J.A., Rarity, F., and Lane, T.I., 2017 Anatomy of a shoreline regression: implications for the high-resolution stratigraphic architecture of deltas: Journal of Sedimentary Research, v. 87, p. 425-459. doi:10.2110 jsr.2017.26

Aslan, A., Autin, W.J., And Blum, M.D., 2005, Causes of river avulsion: insights from the late Holocene avulsion history of the Mississippi River, U.S.A: Journal of Sedimentary Research, v. 75, p. 650-664.

Best, J.L., AND Ashworth, P.J., 1997, Scour in large braided rivers and the recognition of sequence stratigraphic boundaries: Nature, v. 387 , p. 275

BhatTACHARYA, J.P., 2011, Practical problems in the application of the sequence stratigraphic method and key surfaces: integrating observations from ancient fluvialdeltaic wedges with Quaternary and modelling studies: Sedimentology, v. 58, p. 120 169.

Bintanja, R., van de Wal, R.S.W., and Oerlemans, J., 2005, Modelled atmoshperic temperatures and global sea levels over the past million years: Nature, v. 437, p. 125 128.

Blum, M.D., AND Aslan, A., 2006, Signatures of climate vs. sea-level change within incised valley-fill successions: Quaternary examples from the Texas Gulf Coast: Sedimentary Geology, v. 190, p. 177-211.

Blum, M.D., AND TörnqvisT, T.E., 2000, Fluvial responses to climate and sea-level change a review and look forward: Sedimentology, v. 47, p. 2-48.

Blum, M., Martin, J., Milliken, K., and Garvin, M., 2013, Paleovalley systems: insights from Quaternary analogs and experiments: Earth-Science Reviews, v. 116, p. 128-169.

Bromley, M.H., 1991, Architectural features of the Kayenta Formation (Lower Jurassic), Colorado Plateau, USA: relationship to salt tectonics in the Paradox Basin: Sedimentary Geology, v. 73, p. 77-99.

Castelltort, S., and Van Den Driessche, J., 2003, How plausible are high-frequency sediment supply-driven cycles in the stratigraphic record?: Sedimentary Geology, v. 157, p. $3-13$.

Catuneanu, O., and Zecchin, M., 2013, High-resolution sequence stratigraphy of clastic shelves II: controls on sequence development: Marine and Petroleum Geology, v. 39, p $26-38$

Chadwick, A.J., Lamb, M.P., Moodie, A.J., Parker, G., And Nittrouer, J.A., 2019, Origin of a preferential avulsion node on lowland river deltas: Geophysical Research Letters, v. 46, p. $4267-4277$.

Chatanantavet, P., And Lamb, M.P., 2014, Sediment transport and topographic evolution of a coupled river and river plume system: an experimental and numerical study: Journal of Geophysical Research, Earth Surface, v. 119, p. 1263-1282.

Chatanantavet, P., Lamb, M.P., And NitTrouer, J.A., 2012, Backwater controls of avulsion location on deltas: Geophysical Research Letters, v. 39, L01402.

Colombera, L., Shiers, M.N., And Mountney, N.P., 2016, Assessment of backwater controls on the architecture of distributary-channel fills in a tide-influenced coastal-plain succession: Campanian Neslen Formation, U.S.A: Journal of Sedimentary Research, v. 86, p. 476-497. doi:10.2110/jsr.2016.33

Dalman, R., Weltje, G.J., and Karamitopoulos, P., 2015, High-resolution sequence stratigraphy of fluvio-deltaic systems: prospects of system-wide chronostratigraphic correlation: Earth and Planetary Science Letters, v. 412, p. 10-17.

Durkin, P.R., Boyd, R.L., Hubbard, S.M., Shultz, A.W., and Blum, M.D., 2017, Threedimensional reconstruction of meander-belt evolution, Cretaceous McMurray Formation, Alberta Foreland Basin, Canada: Journal of Sedimentary Research, v. 87, p. 1075-1099 doi:10.2110/jsr.2017.59

EDMONDS, D.A., 2012, Stability of backwater-influenced river bifurcations: a study of the Mississippi-Atchafalaya system: Geophysical Research Letters, v. 39

EILERTSEn, R.S., AND Hansen, L., 2008, Morphology of river bed scours on a delta plain revealed by interferometric sonar: Geomorphology, v. 94, p. 58-68.

Engelund, F., And Hansen, E., 1967, A Monograph on Sediment Transport in Alluvial Streams: Denmark, Teknisk Forlag Kobenhavn, 65 p.
Fernandes, A.M., Törnqvist, T.E., Straub, K.M., and Mohrig, D., 2016, Connecting the backwater hydraulics of coastal rivers to fluviodeltaic sedimentology and stratigraphy: Geology, v. 44, p. 979-982.

Foreman, B.Z., AND Straub, K.M., 2017, Autogenic geomorphic processes determine the resolution and fidelity of terrestrial paleoclimate records: Science Advances, v. 3, e1700683.

Ganti, V., Straub, K.M., Foufoula-Georgiou, E., and Paola, C., 2011, Space-time dynamics of depositional systems: experimental evidence and theoretical modeling of heavy-tailed statistics: Journal of Geophysical Research, Earth Surface, v. 116, F02011. Ganti, V., Paola, C., and Foufoula-Georgiou, E., 2013, Kinematic controls on the geometry of the preserved cross sets: Journal of Geophysical Research, Earth Surface, v. 118 , p. $1296-1307$

Ganti, V., Chu, Z., Lamb, M.P., Nittrouer, J.A., And Parker, G., 2014a, Testing morphodynamic controls on the location and frequency of river avulsions on fans versus deltas: Huanghe (Yellow River), China: Geophysical Research Letters, v. 41, p. 78827890.

Ganti, V., Lamb, M.P., AND McElroy, B., 2014b, Quantitative bounds on morphodynamics and implications for reading the sedimentary record: Nature Communications, v. 5, p. 1-

Ganti, V., Chadwick, A.J., Hassenruck-Gudipati, H.J., Fuller, B.M., and Lamb, M.P., 2016a, Experimental river delta size set by multiple floods and backwater hydrodynamics: Science Advances, v. 2, e1501768.

Ganti, V., Chadwick, A.J., Hassenruck-Gudipati, H.J., and Lamb, M.P., 2016b, Avulsion cycles and their stratigraphic signature on an experimental backwater-controlled delta: Journal of Geophysical Research, Earth Surface, v. 121, p. 1651-1675.

GiBLing, M.R., 2006, Width and thickness of fluvial channel bodies and valley fills in the geological record: a literature compilation and classification: Journal of Sedimentary Research, v. 76, p. 731-770.

Gross, M.G., 1977, Oceanography: A View of the Earth: Englewood Cliffs, New Jersey, Prentice-Hall, $503 \mathrm{p}$.

Hajek, E.A., and Straub, K.M., 2017, Autogenic sedimentation in clastic stratigraphy: Annual Review of Earth and Planetary Sciences, v. 45, p. 681-709.

Hamilton, P.B., Strom, K., and Hoyal, D.C.J.D., 2013, Autogenic incision-backfilling cycles and lobe formation during the growth of alluvial fans with supercritical distributaries: Sedimentology, v. 60, p. 1498-1525.

HAMPson, G.J., 2016, Towards a sequence stratigraphic solution set for autogenic processes and allogenic controls: Upper Cretaceous strata, Book Cliffs, Utah, USA: Geological Society of London, Journal, v. 173, p. 817-836.

Helland-Hansen, W., and Martinsen, O.J., 1996, Shoreline trajectories and sequences: description of variable depositional-dip scenarios: Journal of Sedimentary Research, v 66 , p. $670-688$

JERolmack, D.J., 2009, Conceptual framework for assessing the response of delta channel networks to Holocene sea-level rise: Quaternary Science Reviews, v. 28, p. 1786-1800. Jerolmack, D.J., and Mohrig, D., 2007, Conditions for branching in depositional rivers: Geology, v. 35, p. 463-466.

Jerolmack, D.J., and Paola, C., 2010, Shredding of environmental signals by sediment transport: Geophysical Research Letters, v. 37, L19401.

Jerolmack, D.J., and Swenson, J.B., 2007, Scaling relationships and evolution of distributary networks on wave-influenced deltas: Geophysical Research Letters, v. 34, L23402.

Jones, L.S., AND Schumm, S.A., 1999, Causes of avulsions: an overview, in Smith, N.D., and Rogers, J., eds., Fluvial Sedimentology VI: International Association of Sedimentologists, Special Publication 28, p. 171-178.

Karamitopoulos, P., Weltje, G.J., and Dalman, R.A.F., 2014, Allogenic controls on autogenic variability in fluvio-deltaic systems: inferences from analysis of synthetic stratigraphy: Basin Research, v. 26, p. 767-779.

Kim, W., Paola, C., Swenson, J.B., and Voller, V.R., 2006, Shoreline response to autogenic processes of sediment storage and release in the fluvial system: Journal of Geophysical Research, Earth Surface, v. 111, F04013.

Kim, W., Petter, A., Straub, K.M., and Mohrig, D., 2014, Investigating the autogenic process response to allogenic forcing: experimental geomorphology and stratigraphy, in Martinius, A.W., Ravnås, R., Howell, J.A., Steel, R.J., and Womham, J.P., eds., Depositional Systems to Sedimentary Successions on the Norwegian Continental Margin: International Association of Sedimentologists, Special Publication 46, p. 127138

Kraus, M.J., and Middleton, L.T., 1987, Dissected paleotopography and base-level changes in a Triassic fluvial sequence: Geology, v. 15, p. 18-21.

Lamb, M.P., Nittrouer, J.A., Mohrig, D., ANd ShaW, J., 2012, Backwater and river plume controls on scour upstream of river mouths: implications for fluvio-deltaic morphodynamics: Journal of Geophysical Research, Earth Surface, v. 117, F01002.

Lane, E.W., 1957, A Study of the Shape of Channels Formed by Natural Streams Flowing in Erodible Material: U.S. Army Corps of Engineers, Missouri River Division, Sediment Series 9, Report.

Li, Q., Yu, L., AND StRaub, K.M., 2016, Storage thresholds for relative sea-level signals in the stratigraphic record: Geology, v. 44, p. 179-182.

Martin, J., Fernandes, A.M., Pickering, J., Howes, N., Mann, S., and McNeil, K., 2018, The stratigraphically preserved signature of persistent backwater dynamics in a large paleodelta system: the Mungaroo Formation, North West Shelf, Australia: Journal of Sedimentary Research, v. 88, p. $850-872$. doi:10.2110/jsr.2018.38 
MÉTIVIER, F., 1999, Diffusive-like buffering and saturation of large rivers: Physical Review E, v. 60 , p. $5827-5832$.

Miall, A.D., And Arush, M., 2001, Cryptic sequence boundaries in braided fluvial successions: Sedimentology, v. 48, p. 971-985.

Middelkoop, H., Erkens, G., and van der Perk, M., 2010, The Rhine delta: a record of sediment trapping over time scales from millennia to decades: Journal of Soils and Sediments, v. 10 , p. $1-12$.

Mikeš, D., ten Veen, J.H., Postma, G., and Steel, R., 2015, Inferring autogenically induced depositional discontinuities from observations on experimental deltaic shoreline trajectories: Terra Nova, v. 27, p. 442-448.

Milliman, J.D., AND Syvitski, J.P.M., 1992, Geomorphic/tectonic control of sedimen discharge to the ocean: the importance of small mountainous rivers: The Journal of Geology, v. 100, p. 525-544.

Mohrig, D., Heller, P.L., AND Lyons, W.J., 2000, Interpreting avulsion process from ancient alluvial sequences: Guadalope-Matarranya system (northern Spain) and Wasatch Formation (western Colorado): Geological Soceity of America, Bulletin, v. 112, p. 17871803

Nittrouer, J.A., Mohrig, D., Allison, M.A., And Peyret, A.P.B., 2011, The lowermost Mississippi River: a mixed bedrock-alluvial channel: Sedimentology, v. 58, p. 1914 1934.

Nittrouer, J.A., Shaw, J., Lamb, M.P., And Mohrig, D., 2012, Spatial and temporal trends for water-flow velocity and bed-material sediment transport in the lower Mississippi River: Geological Society of America, Bulletin, v. 124, p. 1-15.

PAOLA, C., 2000, Quantitative models of sedimentary basin filling: Sedimentology, v. 47, p. 121-178.

Paola, C., And Mohrig, D., 1996, Palaeohydraulics revisited: palaeoslope estimation in coarse-grained braided rivers: Basin Research, v. 8, p. 243-254.

Paola, C., Heller, P.L., And Angevine, C.L., 1992, The large-scale dynamics of grain-size variation in alluvial basins 1: theory: Basin Research, v. 4, p. 73-90.

Parker, G., Wilcock, P.R., Paola, C., Dietrich, W.E., And Pitlick, J., 2007, Physical basis for quasi-universal relations describing bankfull hydraulic geometry of single-thread gravel bed rivers: Journal of Geophysical Research, Earth Surface, v. 112, F04005.

Posamentier, H.W., and Vall, P.R., 1988, Eustatic controls on clastic deposition II sequence and systems tract models, in Wilgus, C.K., Hastings, B.S., Kendall, C.G.St.C., Posamentier, H.W., Ross, C.A., and Van Wagoner, J.C., eds., Sea-Level Changes: An Integrated Approach: SEPM, Special Publication 42, p. 125-154

Posamentier, H.W., Jervey, M.T., and Vail, P.R., 1988, Eustatic controls on clastic deposition I: conceptual framework, in Wilgus, C.K., Hastings, B.S., Kendall, C.G.St.C., Posamentier, H.W., Ross, C.A., and Van Wagoner, J.C., eds., Sea-Level Changes: An Integrated Approach: SEPM, Special Publication 42, p. 110-124.

Reitz, M.D., Pickering, J.L., Goodbred, S.L., Paola, C., Steckler, M.S., Seeber, L., AND AKHTER, S.H., 2015, Effects of tectonic deformation and sea level on river path selection theory and application to the Ganges-Brahmaputra-Meghna River Delta: Journal of Geophysical Research, Earth Surface, v. 120, p. 671-689.

Rohling, E.J., Grant, K., Bolshaw, M., Roberts, A., Siddall, M., Hemleben, C., and KuCERA, M., 2009, Antarctic temperatures and global sea level closely coupled over the past five glacial cycles: Nature Geoscience, v. 2, p. 500-504

SAlter, T., 1993, Fluvial scour and incision: models for their influence on the development of realistic reservoir geometries, in North, C.P., and Prosser, D.J., eds., Characterization of Fluvial and Aeolian Reservoirs: Geological Society of London, Special Publication 73 , p. $33-51$.
SHIELDS, A., 1936, Anwendung der Ähnlichkeitsmechanik und der Turbulenzforschung auf die Geschiebebewegung [Application of Similarity Principles and Turbulence Research to Bed-Load Movement]: Preußische Versuchsanstalt für Wasserbau und Schiffbau, v. $26,47 \mathrm{p}$.

Slingerland, R., and Smith, N.D., 2004, River avulsions and their deposits: Annual Review of Earth and Planetary Sciences, v. 32, p. 257-285.

Straub, K.M., Paola, C., Mohrig, D., Wolinsky, M.A., and George, T., 2009, Compensational stacking of channelized sedimentary deposits: Journal of Sedimentary Research, v. 79, p. 673-688.

Straub, K.M., Ganti, V., Paola, C., and Foufoula-Georgiou, E., 2012, Prevalence of exponential bed thickness distributions in the stratigraphic record: experiments and theory: Journal of Geophysical Research, Earth Surface, v. 117, F02003.

Strong, N., and Paola, C., 2008, Valleys that never were: time surfaces versus stratigraphic surfaces: Journal of Sedimentary Research, v. 78, p. 579-593.

SYvitSKI, J.P.M., AND SAITO, Y., 2007, Morphodynamics of deltas under the influence of humans: Global and Planetary Change, v. 57, p. 261-282.

Trower, E.J., Ganti, V., Fischer, W.W., AND LAmb, M.P., 2018, Erosional surfaces in the Upper Cretaceous Castlegate Sandstone (Utah, USA): sequence boundaries or autogenic scour from backwater hydrodynamics?: Geology, v. 46, p. 707-710.

van DiJk, M., Postma, G., and Kleinhans, M.G., 2009, Autocyclic behaviour of fan deltas: an analogue experimental study: Sedimentology, v. 56, p. 1569-1589.

van Dijk, M., Kleinhans, M.G., Postma, G., and Kraal, E., 2012, Contrasting morphodynamics in alluvial fans and fan deltas: effect of the downstream boundary: Sedimentology, v. 59, p. 2125-2145.

VAN WAGONER, J.C., 1991, High-frequency sequence stratigraphy and facies architecture of the Sego Sandstone in the Book Cliffs of western Colorado and eastern Utah, in Van Wagoner, J.C., Nummedal, D., Jones, C.R., Taylor, D.R., Jeanette, D.C., and Riley, G.W., eds., Sequence Stratigraphy Applications to Shelf Sandstone Reservoirs: Outcrop to Subsurface Examples: American Association of Petroleum Geologists, Field Conference, p. 1-22.

VAN WAGONER, J.C., 1995, Sequence stratigraphy and marine to non-marine facies architecture of foreland basin strata, Book Cliffs, Utah, U.S.A., in Van Wagoner, J.C., and Bertram, G.T., eds., Sequence Stratigraphy of Foreland Basin Deposits: American Association of Petroleum Geologits, Memoir 64, p. 137-223.

Van Wagoner, J.C., Mitchum, R.M., JR., Posamentier, H.W., and Vail, P.R., 1987, Seismic stratigraphy interpretation using sequence stratigraphy: Part 2: key definitions of sequence stratigraphy, in Bally, A.W., ed., Atlas of Seismic Stratigraphy, v. 1: American Association of Petroleum Geologists, Studies in Geology 27, p. 11-14.

Van Wagoner, J.C., Mitchum, R.M., Campion, K.M., and Rahmanian, V.D., 1990 Siliciclastic Sequence Stratigraphy in Well Logs, Cores, and Outcrops: Concepts for High-Resolution Correlation of Time and Facies: American Association of Petroleum Geologists, Methods in Exploration Series, no. 7, 55 p.

Wright, S., AND PARKer, G., 2004, Flow resistance and suspended load in sand-bed rivers: simplified stratification model: Journal of Hydraulic Engineering, v. 130, p. 796-805.

Yu, L., Li, Q., AND Straub, K.M., 2017, Scaling the response of deltas to relative-sea-leve cycles by autogenic space and time scales: a laboratory study: Journal of Sedimentary Research, v. 87, p. 817-837. doi:10.2110/jsr.2017.46

Received 26 November 2018; accepted 3 May 2019 
APPENDIX: NOTATION

\begin{tabular}{|c|c|c|}
\hline Parameter & Symbol & Dimension \\
\hline Maximum vertical depth of erosion & $h_{\text {scour }}$ & $\mathrm{L}$ \\
\hline Difference between normal flow depths of typical low and high flows & $\Delta h$ & $\mathrm{~L}$ \\
\hline Characteristic flow depth & $h_{c}$ & $\mathrm{~L}$ \\
\hline Critical amount of in-channel sedimentation required to initiate an avulsion & $h_{\text {fill }}$ & $\mathrm{L}$ \\
\hline Dimensionless avulsion threshold & $h^{*}$ & - \\
\hline Volumetric sediment flux per unit channel width & $q_{s}$ & $\mathrm{~L}^{2} / \mathrm{T}$ \\
\hline Channel-bed slope & $S$ & $\mathrm{~L} / \mathrm{L}$ \\
\hline Channel-bed elevation & $\eta$ & $\mathrm{L}$ \\
\hline Diffusivity & $\kappa$ & $\mathrm{L}^{2} / \mathrm{T}$ \\
\hline Length scale of autogenic erosional scours & $l_{\text {scour }}$ & $\mathrm{L}$ \\
\hline Timescale of an erosion-inducing event (flood or avulsion) & $t_{\text {scour }}$ & $\mathrm{T}$ \\
\hline Characteristic backwater length scale & $L_{b}$ & $\mathrm{~L}$ \\
\hline Characteristic bed-adjustment timescale in the backwater zone & $t_{\text {adj }}$ & $\mathrm{T}$ \\
\hline Median grain size & $D_{50}$ & $\mathrm{~L}$ \\
\hline Submerged specific density of sediment & $R$ & - \\
\hline Bed friction coefficient & $C_{f}$ & - \\
\hline Shields number & $\tau_{*}$ & - \\
\hline Normal flow depth for a given flood event & $h_{n}$ & $\mathrm{~L}$ \\
\hline Length of delta-front progradation during an avulsion cycle & $D_{p}$ & $\mathrm{~L}$ \\
\hline Amount of relative sea-level rise (or fall) during an avulsion cycle & $z$ & $\mathrm{~L}$ \\
\hline Characteristic reoccurrence timescale of avulsions & $t_{A}$ & $\mathrm{~T}$ \\
\hline Relative sea-level rise (or fall) rate & $\sigma$ & $\mathrm{L} / \mathrm{T}$ \\
\hline Number of delta lobes tied to given avulsion nodes & $N$ & - \\
\hline Number of avulsions before a given lobe is reoccupied & $n$ & - \\
\hline Avulsion length & $L_{A}$ & $\mathrm{~L}$ \\
\hline Basin depth & $B$ & $\mathrm{~L}$ \\
\hline Dimensionless avulsion timescale & $t_{A}^{*}$ & - \\
\hline Dimensionless basin depth & $B^{*}$ & - \\
\hline Dimensionless avulsion length & $L_{A}^{*}$ & - \\
\hline Dimensionless relative sea-level rise (or fall) rate & $\sigma^{*}$ & - \\
\hline Time & $t$ & $\mathrm{~T}$ \\
\hline Streamwise distance & $x$ & $\mathrm{~L}$ \\
\hline Acceleration due to gravity & $g$ & $\mathrm{~L} / \mathrm{T}^{2}$ \\
\hline Density of sediment & $\rho_{s}$ & $\mathrm{M} / \mathrm{L}^{3}$ \\
\hline Water discharge & $Q_{w}$ & $\mathrm{~L}^{3} / \mathrm{T}$ \\
\hline Froude number & $\mathrm{Fr}$ & - \\
\hline
\end{tabular}

